Keywords: Tritium

Polymers

Radiation Damage

Radiolysis

Retention - Permanent

\title{
Effects of Tritium Gas Exposure on EPDM Elastomer
}

\author{
Elliot A. Clark \\ Materials Science and Technology
}

Publication Date: 11 December 2009

Savannah River National Laboratory

Savannah River Nuclear Solutions

Aiken, SC 29808

Prepared for the U.S. Department of Energy Under

Contract Number DE-AC09-08SR22470

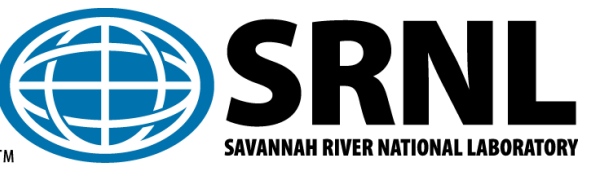




\section{DISCLAIMER}

This work was prepared under an agreement with and funded by the U.S. Government. Neither the U. S. Government or its employees, nor any of its contractors, subcontractors or their employees, makes any express or implied:

1. warranty or assumes any legal liability for the accuracy, completeness, or for the use or results of such use of any information, product, or process disclosed; or

2. representation that such use or results of such use would not infringe privately owned rights; or 3. endorsement or recommendation of any specifically identified commercial product, process, or service. Any views and opinions of authors expressed in this work do not necessarily state or reflect those of the United States Government, or its contractors, or subcontractors.

Printed in the United States of America

Prepared for

U.S. Department of Energy 


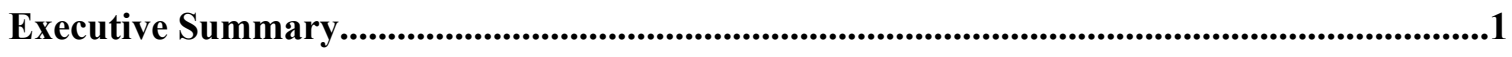

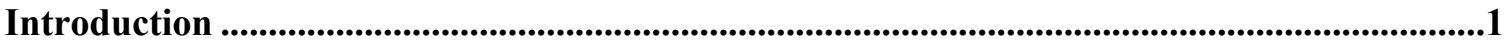

Sample Exposure

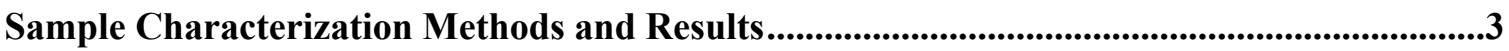

Mass, Volume, and Density..........................................................................................................................3

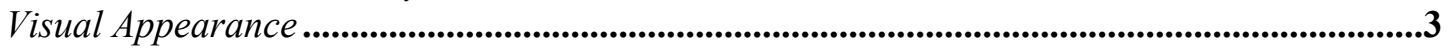

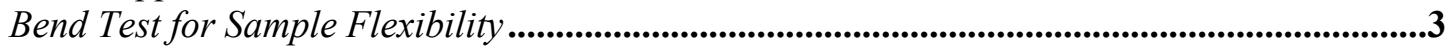

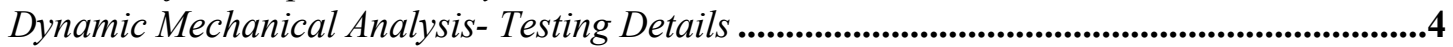

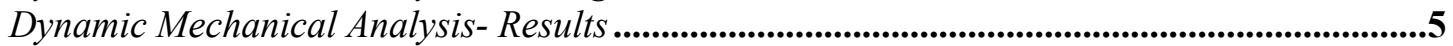

Glass Transition Temperature Determination ...........................................................................................5

Frequency Dependence ........................................................................................................................6

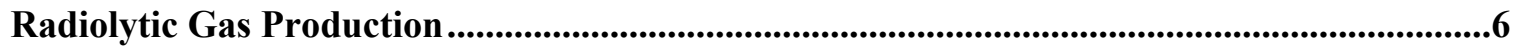

Summary and Conclusions ..............................................................................................................

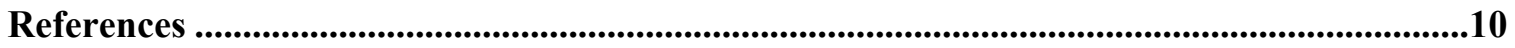

Figures ..................................................................................................................................................................11 


\section{TABLES}

I. Materials, Planned Exposure Times, Actual Exposure Times .............................................

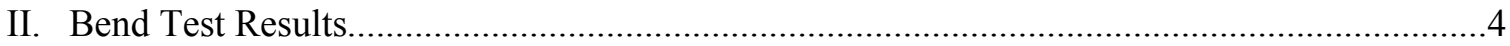

III. Curies tritium in samples, curies per unit sample volume in polymers, and total moles gas produced per year per unit volume for each polymer

\section{FIGURES}

1. Photograph of Tritium Exposure Container

2. Percent mass, volume, density change with tritium exposure

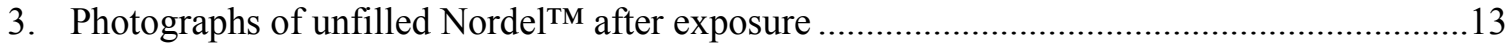

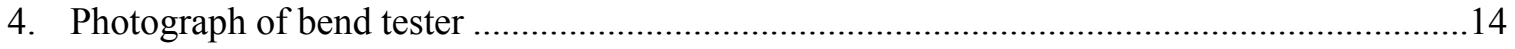

5. Photograph of unfilled Royalene ${ }^{\circledR}$ sample after bend test

6. Storage modulus, loss modulus, and $\tan \delta$ of filled Nordel ${ }^{\mathrm{TM}}$ with increasing temperature $\ldots . .15$

7. Storage modulus, loss modulus, and $\tan \delta$ of filled Royalene ${ }^{\circledR}$ with increasing temperature. 16

8. Storage modulus, loss modulus, and $\tan \delta$ of unfilled Nordel ${ }^{\mathrm{TM}}$ with increasing temperature

9. Storage modulus, loss modulus, and $\tan \delta$ of unfilled Royalene ${ }^{\circledR}$ with increasing temperature

10. Storage and loss modulus of filled Nordel ${ }^{\mathrm{TM}}$ with increasing temperature- glass transition temperature determination ......

11. Glass Transition temperature versus tritium exposure time for all samples

12. Storage modulus, loss modulus, tan delta of filled and unfilled Nordel ${ }^{\mathrm{TM}}$

13. Loss modulus of filled and unfilled Nordel ${ }^{\mathrm{TM}}$ with $1,3,10 \mathrm{~Hz}$ applied frequency ......

14. Gas composition after 420 days tritium exposure

15. Moles of molecular species in container after tritium exposures- filled Nordel ${ }^{\mathrm{TM}}$ and filled Royalene $\AA$

16. Moles of molecular species in container after tritium exposures- unfilled Nordel ${ }^{\mathrm{TM}}$ and unfilled Royalene ${ }^{\circledR}$.

17. Predicted and measured moles of ${ }^{3} \mathrm{He}$ and $\mathrm{T}_{2}$ with exposure time 


\section{Effects of Tritium Gas Exposure on EPDM Elastomer (U)}

\section{EXECUTIVE SUMMARY}

Samples of four formulations of ethylene-propylene diene monomer (EPDM) elastomer were exposed to initially pure tritium gas at one atmosphere and ambient temperature for various times up to about 420 days in closed containers. Two formulations were carbon-black-filled commercial formulations, and two were the equivalent formulations without filler synthesized for this work. Tritium effects on the samples were characterized by measuring the sample volume, mass, flexibility, and dynamic mechanical properties and by noting changes in appearance. The glass transition temperature was determined by analysis of the dynamic mechanical properties. The glass transition temperature increased significantly with tritium exposure, and the unfilled formulations ceased to behave as elastomers after the longest tritium exposure. The filled formulations were more resistant to tritium exposure. Tritium exposure made all samples significantly stiffer and therefore much less able to form a reliable seal when employed as O-rings. No consistent change of volume or density was observed; there was a systematic lowering of sample mass with tritium exposure. In addition, the significant radiolytic production of gas, mainly protium $\left(\mathrm{H}_{2}\right)$ and HT, by the samples when exposed to tritium was characterized by measuring total pressure in the container at the end of each exposure and by mass spectroscopy of a gas sample at the end of each exposure. The total pressure in the containers more than doubled after $\sim 420$ days tritium exposure.

\section{INTRODUCTION}

The unique properties of polymers make them indispensable for certain parts in tritium gas transfer systems. Specifically, the resiliency of elastomers is ideal for sealing surfaces, for example in valves. EPDM, ethylene propylene diene monomer elastomer, is a hydrocarbon polymer used extensively for sealing applications. EPDM is used for its excellent combination of properties including a wide operating temperature range, radiation resistance, aging resistance, and good mechanical properties. This study characterized effects of tritium gas exposure on samples of two formulations of EPDM, Nordel ${ }^{\mathrm{TM}} 1440$ and Royalene ${ }^{\circledR} 580 \mathrm{H}$. Both commercially obtained carbon-black-filled formulations and formulations without filler were tested. Results of one week [1] and 3-4 months [2] tritium exposures have been documented earlier. This report documents all sample exposure and property characterizations and radiolytic gas production for tritium exposures for as long as 421 days.

\section{SAMPLE EXPOSURE}

Sheets of Nordel ${ }^{\mathrm{TM}} 1440$ and Royalene ${ }^{\circledR} 580 \mathrm{H}$ were obtained from LANL. Sheets of both standard carbon black filled commercial formulations and formulations synthesized without filler at LANL were provided. The crosslink density of the formulations was the same. The filled Nordel ${ }^{\mathrm{TM}}$ had a nominal thickness of 1.94 $\mathrm{mm}$, the filled Royalene ${ }^{\circledR} 5800.85 \mathrm{~mm}$, the unfilled Nordel ${ }^{\mathrm{TM}} 0.7 \mathrm{~mm}$ and the unfilled Royalene ${ }^{\circledR} 0.65 \mathrm{~mm}$. The filled polymers appeared black, and the unfilled versions appeared light grey before tritium exposure. Rectangular samples having nominal lengths of $33 \mathrm{~mm}$ and nominal width of $9 \mathrm{~mm}$ were cut from the sheets. The samples were weighed and their dimensions measured before and after exposure.

Exposure containers were designed per ASME B31.3 and per Savannah River Site (SRS) Tritium Facility requirements (Fig. 1). The container design limits are a maximum temperature of $500^{\circ} \mathrm{F}$. and maximum pressure of $500 \mathrm{psig}$. The containers (Fig. 1) are 0.75 " internal diameter by 0.049 " wall thickness tubing, about 8" long, connected first to an adapter and then to a series of two bellows valves (Swagelok H-series). All wetted materials of the containers are Type 316 or Type $316 \mathrm{~L}$ stainless steel. 
Spacers were cut from $0.125 \mathrm{~mm}$ thick Type 316 stainless steel sheet. They were cut to be rectangles longer than the sample length $(50 \mathrm{~mm})$ and about the same width as the sample $(9 \mathrm{~mm})$. The spacers were bent around the two ends of each sample to prevent the samples from contacting one other and the exposure container. Except for incidental contact with the spacers, the samples were not intentionally pressed or loaded during exposure.

Each exposure consisted of placing six samples of the same formulation in their spacers in one exposure container. The exposure containers were then attached to a tritium gas system at the Savannah River Site Tritium Facilities. The containers were evacuated overnight, and then back-filled with $100 \%$ tritium gas $\left(\mathrm{T}_{2}\right.$, also designated ${ }^{3} \mathrm{H}_{2}$ ) to about one atmosphere pressure. The container valves were closed, and the samples were exposed to tritium at ambient temperature $\left(26-29^{\circ} \mathrm{C}\right)$ inside the tritium system glovebox for various times.

Planned and actual exposure times for each test are given in Table I:

\begin{tabular}{|l|l|c|}
\hline Material & \multicolumn{1}{|c|}{$\begin{array}{c}\text { Planned } \\
\text { Exposure Time }\end{array}$} & $\begin{array}{c}\text { Actual Exposure time } \\
\text { (d) }\end{array}$ \\
\hline Filled Nordel & 1 Week & 7,11 \\
\hline Filled Royalene & 1 Week & 7 \\
\hline Unfilled Nordel & 1 Week & 7 \\
\hline Unfilled Royalene & 1 Week & 7 \\
\hline Filled Nordel & 3 Months & 108 \\
\hline Filled Royalene & 3 Months & 123 \\
\hline Unfilled Nordel & 3 Months & 122 \\
\hline Unfilled Royalene & 3 Months & 290 \\
\hline Filled Nordel & 6 Months & 282 \\
\hline Unfilled Nordel & 6 Months & 416 \\
\hline Filled Nordel & 12 Months & 416 \\
\hline Filled Royalene & 12 Months & 421 \\
\hline Unfilled Nordel & 12 Months & 421 \\
\hline Unfilled Royalene & 12 Months & \\
\hline
\end{tabular}

Table I. Material, Planned Exposure Time, and Actual Exposure Time for this study.

For the Filled Nordel 1 week study, a second exposure of 7 days was performed to collect gas data that was not collected after the 11 days exposure.

At the end of exposure, the pressure in the closed containers was measured using the tritium system by expanding the container gas into known system volume having a pressure transducer. A "grab sample" of gas was then taken in a separate container for mass spectroscopy analysis of the gas composition at the end of exposure. The container with the samples was then evacuated for several days. The samples were then moved to another building to measure mass and dimensions, visually inspect the samples, and perform a bend test for sample flexibility and Dynamic Mechanical Analysis (DMA).

\section{SAMPLE CHARACTERIZATION METHODS AND RESULTS}

Mass, Volume, and Density

Electronic scales were used to measure sample masses before and after exposure; the scale used before exposure read to $0.0001 \mathrm{~g}$, and the scale used after exposure (in the tritium facility) read to $0.001 \mathrm{~g}$. The length, width, and thickness of each rectangular slab sample were also measured before and after tritium 
exposure- the length and width were measured using a ruler with gradations to $0.5 \mathrm{~mm}$ and the thickness measured by a caliper reading to $0.01 \mathrm{~mm}$. The volume of each sample was calculated by multiplying the measured length, width, and thickness. The sample masses and volumes for all six samples in each exposure set (specific exposure time and formulation) were added, and the percentage change of mass and volume during exposure were found (Fig. 2). The density of each polymer was calculated by dividing the total mass (sum of sample masses) by the total volume (sum of sample volumes) of each set of samples.

The mass of the filled formulations did not change with tritium exposure; however the mass of the unfilled formulations appeared to decrease with increasing tritium exposure- more so for unfilled Nordel ${ }^{\mathrm{TM}}$ than unfilled Royalene ${ }^{\circledR}$ (Fig. 2 a.). No systematic trend in volume change (Fig. 2 b.) or density change (Fig. 2 c.) with exposure was observed. Because of their thickness, the typical mass and volume of the Filled Nordel samples (six samples weighed $4.5 \mathrm{~g}$ and had a volume of about $4 \mathrm{cc}$ ) was greater than those of the others (Filled Royalene $2 \mathrm{~g}, 1.8 \mathrm{cc}$; Unfilled Nordel $1.2 \mathrm{~g}, 1.1 \mathrm{cc}$; Unfilled Royalene $1.3 \mathrm{~g}, 1.2 \mathrm{cc}$ ). The density of the filled formulations (about $1.2 \mathrm{~g} / \mathrm{cc}$ ) was greater than the unfilled formulations $(0.95 \mathrm{~g} / \mathrm{cc})$; this is expected because of the filler material.

\section{Visual Appearance}

All the filled samples had the same deep black color after exposure as before, even as long as 421 days. The unfilled samples became discolored, and the discoloration increased with tritium exposure time (Fig. 3). Samples exposed for about three months were less discolored where the stainless steel spacer was near (Fig. 3 a.) the sample surface. The effect of the spacer in reducing the discoloration was unexpected- the container gas certainly accessed the polymer surface as much from the side having the spacer as from the other side; the spacers were not squeezed onto the samples. The maximum range of tritium beta particles in air is about $6 \mathrm{~mm}$ [3], so the spacers could have reduced the surface dose of beta particles from the gas where the spacer was near the sample surface. The samples exposed for 421 days did not exhibit the spacer shadowing effect (Fig. 3 b.).

None of the spacers appeared discolored or any evidence of EPDM degradation product on them.

\section{Bend Test for Sample Flexibility}

A small bench top vise (Fig. 4) was altered to perform bend tests per ASTM E 290 - 97a "Standard Test Methods for Bend Testing of Materials for Ductility". The test performed was a Semi-Guided test for thin material, Arrangement B. Three of the six samples for each material and exposure time were tested. In exposures up to 126 days, no breaks were observed, and for exposures greater than 282 days all samples broke (Table II.). 


\begin{tabular}{|l|c|l|l|}
\hline Material & $\begin{array}{c}\text { Exposure } \\
\text { time (d) }\end{array}$ & Break & Notes \\
\hline Filled Nordel & 11 & No & \\
\hline Filled Royalene & 7 & No & \\
\hline Unfilled Nordel & 7 & No & \\
\hline Unfilled Royalene & 7 & No & \\
\hline Filled Nordel & 108 & No & \\
\hline Filled Royalene & 123 & No & \\
\hline Unfilled Nordel & 126 & No & $\begin{array}{l}\text { One sample was partially torn; it was } \\
\text { bent at tear during test, didn't break }\end{array}$ \\
\hline Unfilled Royalene & 122 & No & \\
\hline Filled Nordel & 290 & Yes & Clean brake at $\sim 45$ degrees \\
\hline Unfilled Nordel & 282 & Yes & Clean brake at $\sim 60+$ degrees \\
\hline Filled Nordel & 416 & Yes & Bent some, then clean break \\
\hline Filled Royalene & 416 & Yes & $\begin{array}{l}\text { Bent some, then clean break. Bent } \\
\text { more than } 12 \text { mo Nordel }\end{array}$ \\
\hline Unfilled Nordel & 421 & Yes & $\begin{array}{l}\text { Bent some, then clean break. Bent } \\
\text { more than filled version. }\end{array}$ \\
\hline Unfilled Royalene & 421 & Yes & $\begin{array}{l}\text { Bent some, then clean break. Bent } \\
\text { more than filled version. }\end{array}$ \\
\hline
\end{tabular}

Table II. Results of Bend Test. Three samples tested for every material/exposure time- all replicate bend tests were identical.

One of the Unfilled Royalene ${ }^{\circledR} 126$ day exposure samples chosen for DMA testing broke while mounting the sample for DMA, so this sample was bend- tested. It broke, as the other replicates did (Fig. 5).

\section{Dynamic Mechanical Analysis- Testing Details}

Dynamic mechanical analysis measures the elastic and viscoelastic parameters related to small cyclic deformation of materials- storage modulus, loss modulus, and tan delta. The storage modulus is the constant relating the amount of elastic deformation to a given applied load. For sealing applications, the storage modulus must not be too high- the O-ring seals by deforming and contacting intimately with the metallic sealing surfaces. The loss modulus is a measure of the time-dependent deformation under a given load at the applied cycling frequency, and provides insight to the relative amount of molecular motion occurring at the specific applied cycling frequency. Tan delta is the ratio of the loss modulus to the storage modulus, and was the parameter used in old resonant-type DMA tests. Tan delta is also normally reported with storage and loss modulus as a way of comparing DMA data from resonant test with non-resonant tests.

A TA Instruments Model 2980 dynamic mechanical analyzer was used for this study. It is a forced oscillation, non-resonant, constant amplitude instrument. The single-cantilever-beam clamp, or sample holder, was used, being the clamp of choice for measuring the glass transition temperature of elastomers. The oscillation amplitude was chosen to be 40 microns for exposed samples. To choose this amplitude, a socalled "amplitude sweep" was performed in a previous study [1] in which the amplitude was varied. The range of amplitudes that lead to equal DMA parameter (storage modulus, loss modulus, tan delta) measurements reveal the region of "linear viscoelasticty" for the material. In this range, DMA tests reveal true properties of the material, rather than those of the sample size and shape used. DMA tests should always be carried out in the range of linear viscoelasticity. 
Each DMA test involved stabilizing the temperature at the chosen lowest temperature $\left(-70^{\circ} \mathrm{C}\right.$. for most of the tests, higher for some), remaining at this temperature for 10 minutes to further stabilize the temperature around the sample, and then increasing the sample temperature at $1^{\circ} \mathrm{C}$. per minute until the chosen highest temperature $\left(0^{\circ} \mathrm{C}\right.$. for most tests). (When the glass transition temperature was observed to dramatically change in the longest tritium exposed samples, subsequent replicate tests were performed using higher temperatures to attempt to measure the glass transition temperature, see below). The dynamic mechanical properties were continuously measured during the controlled temperature rise. The TA 2980 has both electrical resistance heating and cooling by evaporated cold nitrogen gas from a liquid nitrogen container called the Gas Cooling Accessory (GCA) which is a part of the DMA system. The control software enables optimized control of cooling and heating for a given temperature and heating rate. Data was taken using the DMA Multi-Frequency mode, at frequencies of 1,3 , and $10 \mathrm{~Hz}$. The DMA continuously acquired data at each of the set frequencies in sequence during the increasing temperature scans. The sampling rate was set at $3.0 \mathrm{sec} /$ point, which specifies the time over which data is acquired for each set frequency. The system was calibrated at least once a month during the testing program.

\section{Dynamic Mechanical Analysis- Results}

The storage modulus of unexposed EPDM varied dramatically with temperature. This variation is common among elastomers- at temperatures below the glass transition the storage modulus is much higher than above the glass transition temperature. The loss modulus and tan delta exhibit a maximum, or peak, as a function of temperature- this is also the expected behavior of any elastomer. The effect of tritium exposure is to increase the glass transition temperature, that is both increase the temperature above which the storage modulus dramatically lowers, and the peak temperature of both the loss modulus and tan delta (Figs. 6, 7, 8, 9). The peak value of the loss modulus and tan delta also decreased with increasing tritium exposure. The effect of tritium exposure was greater on the unfilled formulations- both unfilled Nordel ${ }^{\mathrm{TM}}$ and Royalene ${ }^{\circledR}$ showed no peaks in tan delta, and a very low maximum in loss modulus, after the longest tritium exposure (Figs. 8b., $8 \mathrm{c} ., 9 \mathrm{~b} ., 9 \mathrm{c}$.). The glass transition of the unfilled materials has in effect been eliminated by the long tritium exposure.

The storage modulus for both unfilled formulations after 420 days does not display the large variation with temperature characteristic of the glass transition (Figs. 8a., 9a.). Also, the storage modulus of all four materials at the temperatures where the elastomer will be used, above the glass transition, increased significantly with tritium exposure (Figs. 6a., 7a., 8a., 9a.). This means tritium exposure has made the polymer significantly stiffer, and therefore much less able to maintain a reliable seal in service.

\section{Glass Transition Temperature Determination}

The glass transition temperature $\left(\mathrm{T}_{\mathrm{g}}\right)$ is a critical parameter of amorphous polymers and elastomers, particularly for low-temperature applications. The $\mathrm{T}_{\mathrm{g}}$ value represents the molecular transition between "glassy" behavior at low temperature and "rubbery" behavior at higher temperature. Elastomers are always employed above their glass transition temperatures to take advantage of their highly elastic properties, and the effect of tritium is to effectively make all temperatures "cold" as far as the elastomer is concerned. $T_{g}$ is important in sealing applications because elastomers lack the resiliency at temperatures significantly below $\mathrm{T}_{\mathrm{g}}$ that allows them to form a good mechanical seal. After sufficient tritium exposure, the materials studied here become useless for their application because they remain hard and "glassy" at temperatures at which they must seal properly.

There are at least two accepted methods for determining $\mathrm{T}_{\mathrm{g}}$ from DMA data. ASTM E 1640 "Standard Test Method for Assignment of the Glass Transition Temperature by Dynamic Mechanical Analysis" uses the intersection of two tangents of the storage modulus versus temperature curve- the tangent of data below $\mathrm{T}_{\mathrm{g}}$ and the tangent at the inflection point of the sigmoidally changing storage modulus with temperature in the middle of the glass transition. The temperature of the tangents intersection is regarded as being $\mathrm{T}_{\mathrm{g}}$ (Fig. 10). 
The standard requires an applied frequency of $1 \mathrm{~Hz}$ and a temperature increase rate of $1^{\circ} \mathrm{C} /$ minute, which were used in this study. Either linear or logarithmic plots of storage modulus versus temperature can be used for this construction. In this work, the linear plot is used by the analysis software (provided by the DMA manufacturer, TA Instruments). The other accepted method is the peak temperature of the loss modulus (Fig 10) [6].

Tritium exposure significantly increased the glass transition temperature (Fig. 11) of both filled and unfilled materials tested. At the longest tritium exposure, the unfilled formulations could be said to not have a glass transition, but the filled formulations retained their glass transition (Fig. 12). The average peak temperature of the loss modulus was about $7^{\circ} \mathrm{C}$. higher than the average storage modulus tangent intercept for tritium exposures of 4 months or less, and for longer tritium exposures the average loss modulus peak temperature was about $20^{\circ} \mathrm{C}$. higher than the average storage modulus tangent intercept. The longest exposure of unfilled Nordel $^{\mathrm{TM}}$ could not be fit using the tangent intercept method, so $\mathrm{T}_{\mathrm{g}}$ was estimated (Fig. 11) from the temperature of the slight peak in the loss modulus, and then subtracting the average difference for longer tritium exposures.

\section{Frequency Dependence}

The peak temperatures of the loss modulus of both filled and unfilled Nordel ${ }^{\mathrm{TM}}$ increases with applied frequency (Fig. 13). This is expected, and shows that the molecular mechanism that causes the loss modulus to increase with increasing temperature to a maximum and then decline is a so-called "thermally activated" process. The molecules in the polymer vibrate at an average frequency determined by their structure and by the temperature of the sample. When the applied cyclic load frequency coincides with the average molecular vibration frequency, there is the most interaction between the force and the molecular vibrations, and this occurs at the peak temperature of the loss modulus. When the applied frequency is higher, the peak temperature is higher because the coincidence of applied load frequency occurs at a higher temperature. This is reflected in the data (Fig. 13)

The effects of tritium exposure on the viscoelastic properties are the same for the range of frequencies tested. Increasing tritium exposure time reduces the loss modulus at all frequencies, and raises the peak temperature about the same for the frequencies tested $(1,3,10 \mathrm{~Hz})$. The longest exposure of unfilled Nordel ${ }^{\mathrm{TM}}$ reveals no peak at any temperature, and the loss modulus becomes much lower with increasing frequency (Fig. $13 \mathrm{~b}$.). All of these observations are consistent with a mechanism of tritium beta decay forming a largely crosslinked structure, in which the molecule chain vibrations that can occur in unirradiated EPDM in response to the applied stress during the DMA test initially occur at higher temperature because the distance between cross-links has decreased, and eventually with enough tritium dose the molecular vibrations no longer take place at all. The effects of tritium on tan delta are identical to that of the loss modulus, and also Royalene ${ }^{\circledR}$ behaves identically to Nordel $^{\mathrm{TM}}$.

\section{RADIOLYTIC GAS PRODUCTION}

At the end of each exposure, the total pressure in the sample container was measured by attaching the container to a tritium manifold, and opening valves to a pressure transducer. The volumes of manifold components were calibrated, so the final pressure that existed in the closed container at the end of the exposure was calculated using the measured pressure and manifold component volumes. Also, a sample of the gas at the end of exposure was introduced into standard gas sample containers and taken to a mass spectrometer system. The mass spectrometer report contained the mole percent of species analyzed.

The number of moles of each species in the gas was calculated using the Ideal Gas Law:

$$
\begin{aligned}
\text { Moles of Species i }[\mathrm{g}-\mathrm{mol}]= & (\text { mole fraction of i }) *(\text { total pressure }[\mathrm{psia}]) *(\text { sample container free } \\
& \text { volume } \left.\left[\mathrm{cm}^{3}\right]\right) /(\text { gas constant }) /(\text { temperature }[\text { Kelvin }]) \ldots \ldots . . .1
\end{aligned}
$$


The sample container free volume was measured, and was always about $56 \mathrm{~cm}^{3}$; this value is assumed for all containers. The temperature was assumed to be 300 Kelvin, and the gas constant appropriate for the units employed here is 1206 [psia- $\mathrm{cm}^{3} /(\mathrm{g}-\mathrm{mol}) /$ Kelvin].

At short exposure times, the main radiolytic species produced was HT and at longer times, the main produced species became $\mathrm{H}_{2}$ (Figs. 14, 15, 16). The other significant species in the containers were $\mathrm{T}_{2}$, and ${ }^{3} \mathrm{He}$, expected from tritium decay (Fig. 14 a.). Low concentration species detected, less than $1 \%$, included $\mathrm{H}_{2} \mathrm{O}, \mathrm{CH}_{4}, \mathrm{D}_{2} \mathrm{O}$, and $\mathrm{HDO}$ (Fig. 14 b.).

The predicted generation of ${ }^{3} \mathrm{He}$ was calculated using [5]:

$$
\text { Moles }{ }^{3} \mathrm{He}=\text { Initial Moles } \mathrm{T}_{2} * 2 *(1-\exp (-(\text { days exposure }) * \ln 2 /(12.32 \text { years }) /(365.24 \text { days/year })))
$$

in which the tritium half-life is 12.32 years. The predicted generation of ${ }^{3} \mathrm{He}$ agrees well with the values calculated using Eq. 1 and the mass spectroscopy/total pressure data (Fig. 17 a.). The predicted decay of tritium was compared to the measured amount of total tritium by first calculating the actual total tritium measured in the gas:

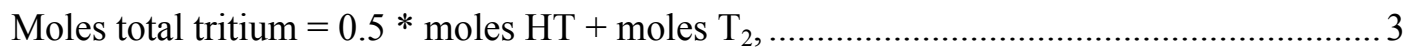

since the only significant gas species with tritium are $\mathrm{HT}$ and $\mathrm{T}_{2}$. The total tritium is the number of moles of $\mathrm{T}_{2}$ gas having the same activity and the mixture of $\mathrm{HT}$ and $\mathrm{T}_{2}$. The predicted decay of tritium was calculated using [5]:

Moles total tritium remaining = Initial Moles $\mathrm{T}_{2} *(\exp (-($ days exposure $) * \ln 2 /(12.32$ years $) /(365.24$

By comparing the measured total tritium in the gas with the predicted total tritium as a function of time, the amount of tritium incorporated into the samples can be seen (Fig. 17 b.)

The amount of tritium incorporated within the polymer samples after 420 days exposure was also estimated by subtracting the moles of tritium remaining in the gas at the end of the exposure from the original moles of tritium at the beginning of exposure. The original moles of tritium were adjusted to account for the radioactive decay over the exposure time. The number of curies tritium in the sample material was found by multiplying by the specific activity of tritium, 58,023 Ci/mol $\mathrm{T}_{2}$ [5] (Table III). The tritium contents were then divided by the total polymer sample volume, resulting in the tritium content per unit volume of the samples (Table III) and the total gas production rate was found by dividing the total moles gas produced by the polymer volume and by the exposure time (Table III). 


\begin{tabular}{|l|c|c|c|}
\hline Material & $\begin{array}{c}\text { Ci T } \\
\text { Samples }\end{array}$ & $\begin{array}{c}\text { Ci/cc } \mathbf{T}_{\mathbf{2}} \text { in } \\
\text { polymer }\end{array}$ & $\begin{array}{c}\text { Moles Gas } \\
\text { Produced /year } \\
\text { /cc polymer }\end{array}$ \\
\hline Filled Nordel & 46.7 & 11.93 & $1.04 \mathrm{E}-03$ \\
\hline Filled Royalene & 29.4 & 16.50 & $1.65 \mathrm{E}-03$ \\
\hline Unfilled Nordel & 48.0 & 38.15 & $3.00 \mathrm{E}-03$ \\
\hline $\begin{array}{l}\text { Unfilled } \\
\text { Royalene }\end{array}$ & 45.8 & 33.35 & $2.66 \mathrm{E}-03$ \\
\hline
\end{tabular}

Table III. Curies tritium in samples, curies per unit sample volume in polymers, and total moles gas produced per year per unit volume for each polymer (420 days exposure).

The average tritium content per unit volume in the unfilled polymers was about 2.5 times that in the filled polymers, and the average gas production rate per unit volume of the unfilled formulations was about twice as much for the filled formulations. These observations mean that filled polymers are more resistant to tritium uptake than unfilled versions.

\section{SUMMARY and CONCLUSIONS}

Samples of four formulations of EPDM elastomers, carbon-black-filled and unfilled Nordel ${ }^{\mathrm{TM}} 1440$ and filled and unfilled Royalene ${ }^{\circledR} 580 \mathrm{H}$, were exposed to tritium gas at one atmosphere for times up to about 420 days.

- The mass of the unfilled formulations became less with tritium exposure. Otherwise, the mass of the filled formulations and the volume and calculated density of the samples did not vary systematically with exposure time.

- The light grey unfilled formulations darkened and became slightly brown; the darkening increased with tritium exposure.

- Stainless steel spacers near the surface of the sample lessened the darkening locally of the unfilled samples exposed for about four months, by blocking beta radiation from the gas. No sign of degradation products were observed on the spacers, even after 420 days exposure.

- Exposure for greater than about four months embrittled the samples- they failed a standard break test. The samples retained their flexibility if only exposed for four months or less. No difference in flexibility between the formulations was observed.

- The glass transition temperature increased with tritium exposure time. At 420 days exposure, the glass transition temperature of the unfilled formulations was much higher than the filled formulations. The variation of the dynamic mechanical properties with temperature revealed that at this long exposure, the unfilled polymers effectively ceased to be elastomers.

- Tritium exposure stiffened (storage modulus increased significantly) all the materials tested considerably above the glass transition. This makes these materials much less effective as seals under these conditions.

- Significant quantities of gas were produced- mainly $\mathrm{HT}$ and $\mathrm{H}_{2}$. The total pressure in the containers more than doubled after 420 days exposure. The generation rate of 3-helium was observed to be about the same as that predicted by radioactive decay of the initial amount of tritium.

- Accounting for the initial tritium put in the sample exposure container, and the final gas composition, significant amounts of tritium were absorbed by all samples. 
From these observations, it can be concluded that tritium exposure significantly degrades the properties of EPDM and produces significant quantities of $\mathrm{H}_{2}$ and HT. The filled formulations of these elastomers are more resistant to tritium degradation and produce less radiolytic gas than unfilled formulations, and there are significant isotope exchange reactions between tritium gas and EPDM elastomers.

\section{ACKNOWLEDGEMENTS}

It is a pleasure to acknowledge: Wanda Britt and Pamela Morgan for sample characterization before testing, sample tracking and handling, mass and volume measurements, DMA operation, hood decontamination, waste management; Mike Thomas for DMA installation and facility interface; Kipp Neikirk for exposure container design and procurement; Greg Staack and Dante Pilgrim for tritium exposure and sample transport. 


\section{REFERENCES}

1) E.A. Clark, "Effects of One Week Tritium Exposure on EPDM Elastomer". Report SRNL-STI-200800524 rev. 0, Savannah River National Laboratory, Washington Savannah River Company, Aiken SC (7 June 2007).

2) E.A. Clark, M.C. Kane, "Effects of Tritium Gas Exposure on the Glass Transition Temperature of EPDM Elastomer and on the Conductivity of Polyaniline". Report SRNL-STI-2008-00522 rev.0, Savannah River National Laboratory, Savannah River Site, Aiken SC (12 December 2008).

3) "Tritium and its Compounds", E. A. Evans, D. Van Nostrand Co., Princeton, NJ USA (1966), p. 2.

4) E.A. Clark, K.L. Shanahan, "Effects of Tritium on UHMW-PE, PTFE, and Vespel ${ }^{\circledR}$ polyimide". Fusion Science and Technology, Vol. 52, Number 4, November 2007, pp. 1007-1011.

5) DOE Handbook: Tritium Handling and Safe Storage. US Department of Energy Handbook, Appendix A, DOE-HDBK 1129-2007 (2007). URL:

http://www.hss.energy.gov/NuclearSafety/techstds/standard/hdbk1129/hdbk1129-07.pdf

6) "Mechanical Properties of Polymers and Composites", 2nd Ed., L.E. Nielsen, R.F. Landel, Marcel Dekker, Inc, New York (1994) p. 141. 


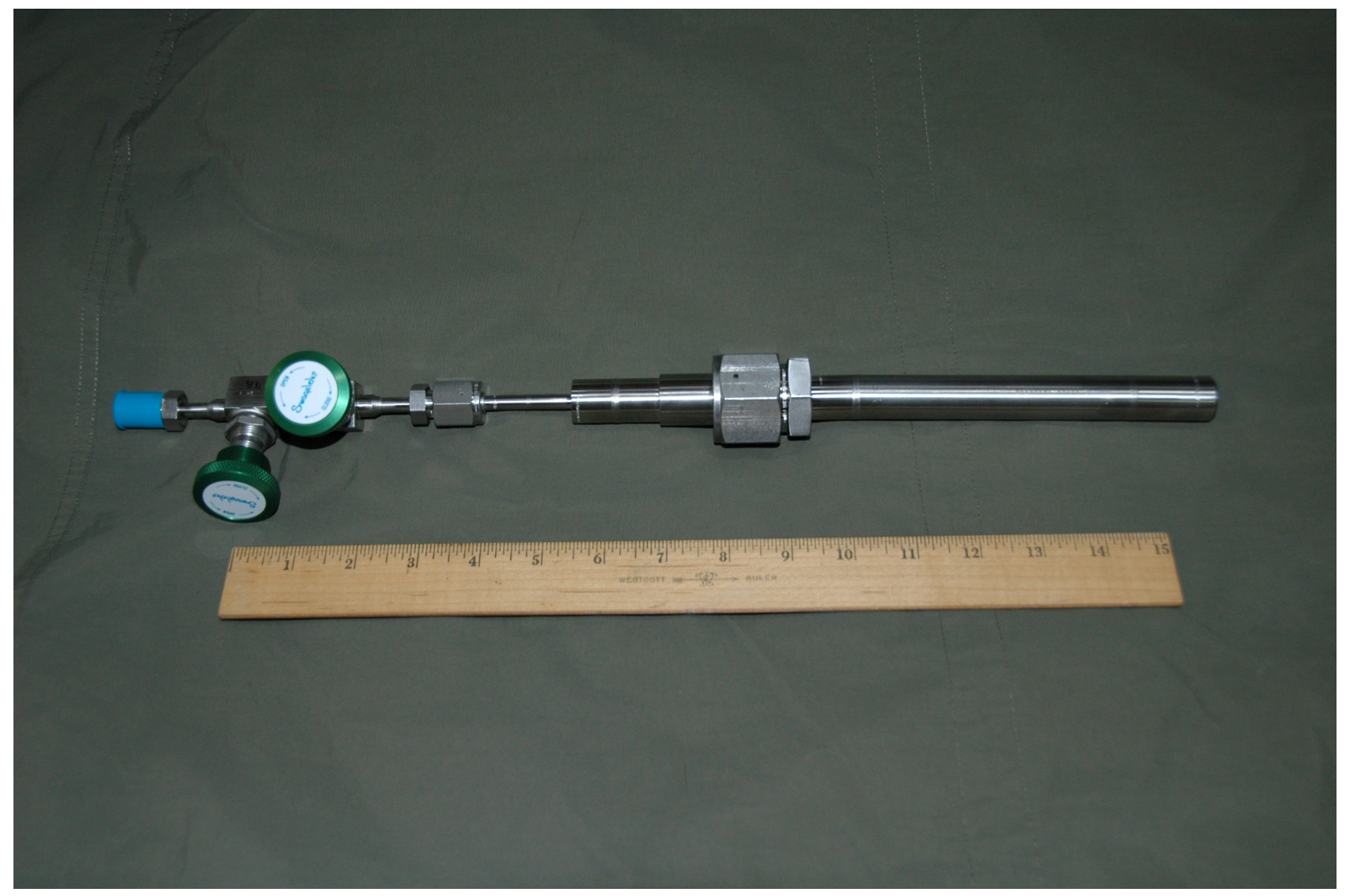

Figure 1.Photograph of Tritium Exposure Container. 


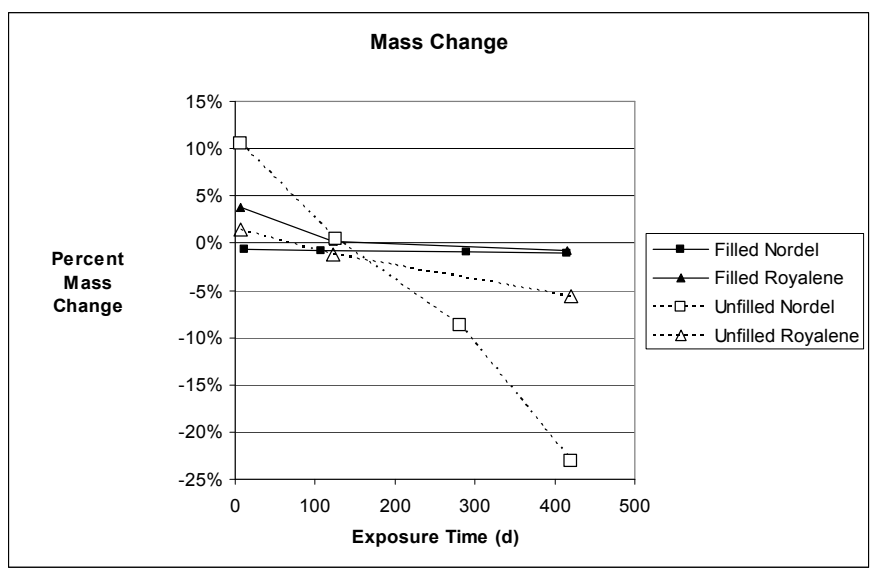

a.

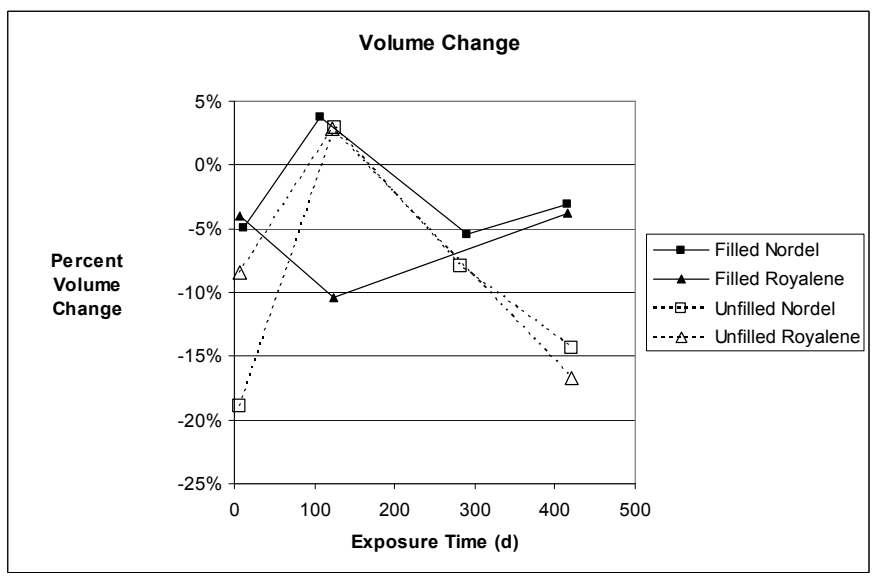

b.

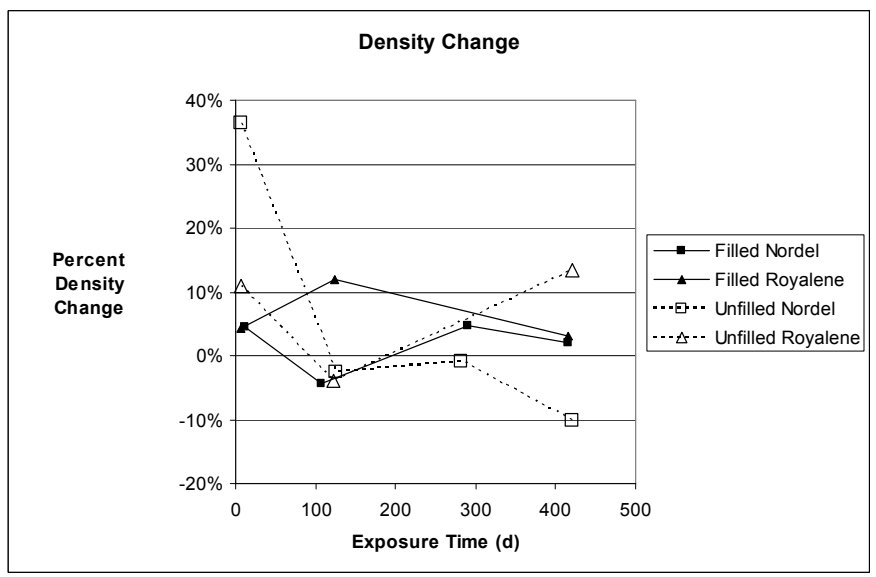

c.

Figure 2. Percent mass (a.), volume (b.), and resulting density (c.) change of EPDM samples as a function of tritium exposure time in days. 


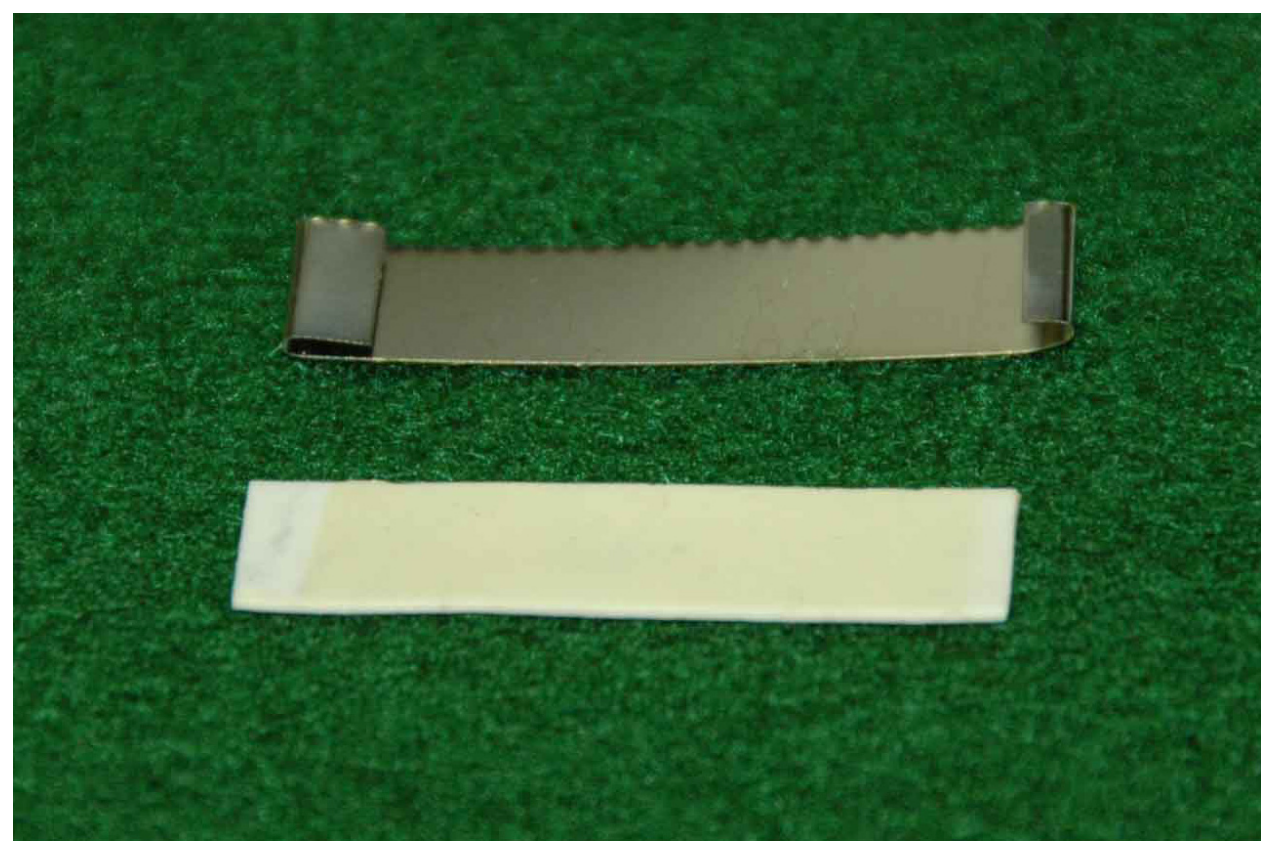

a. Unfilled Nordel ${ }^{\mathrm{TM}}$ and spacer (above), 126 days exposure (note lighter color at sample ends corresponding to spacer)

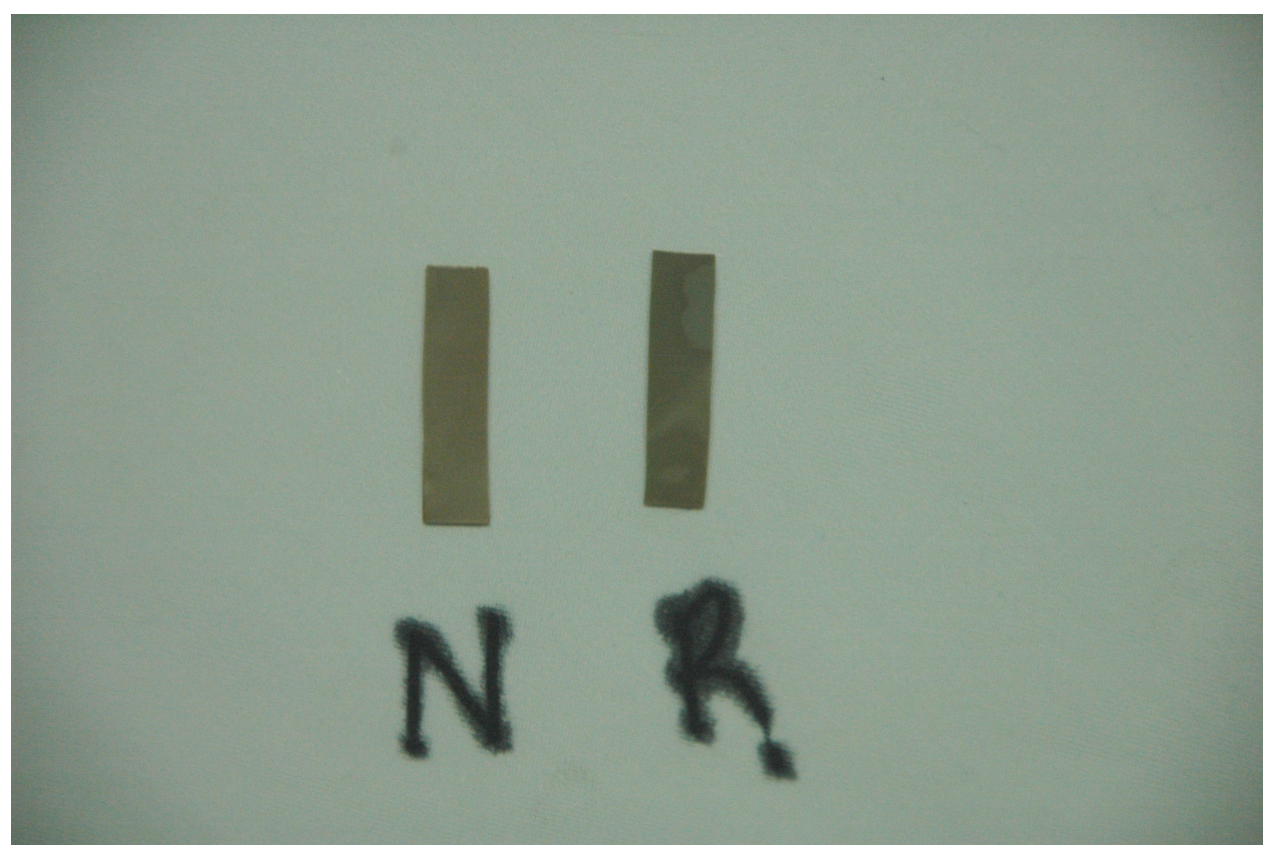

b. "N" Unfilled Nordel ${ }^{\mathrm{TM}}$, "R" Royalene $\AA$, both 421 days exposure

Figure 3. Photographs of unfilled samples after tritium exposure, formulations and exposure time indicated. 


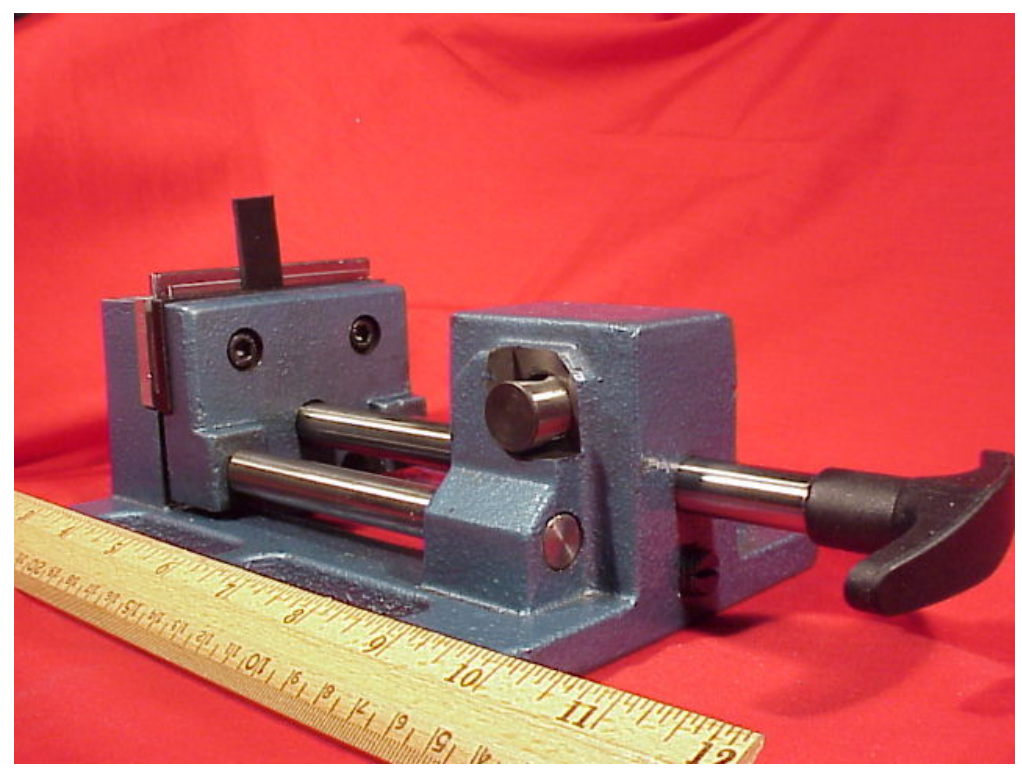

Figure 4. Photograph of Bend Tester, ASTM E 290 - 97a; Semi-Guided Bend, Thin Material. Note filled EPDM sample in position for bend.

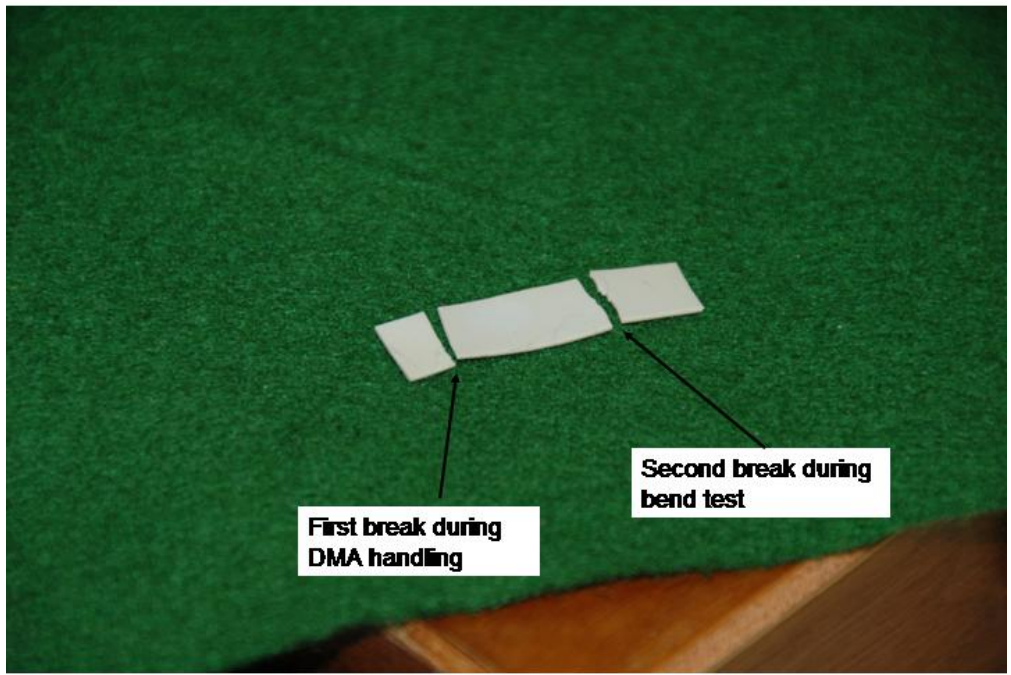

Figure 5. Photograph of unfilled Royalene ${ }^{\circledR}$ sample after 120 days exposure, with two breaks as indicated- one during handling to attempt DMA measurement, the other during a bend test. 


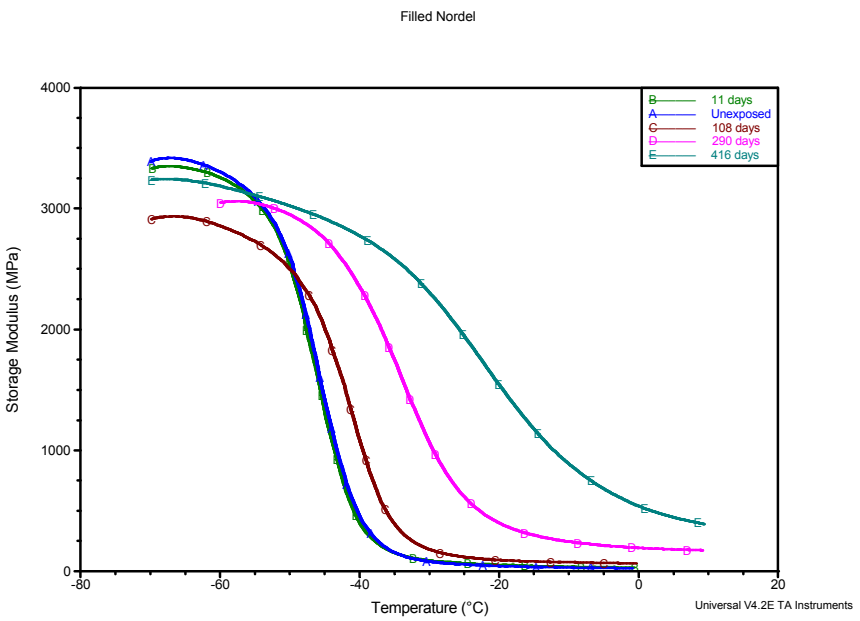

a.

Loss Modulus

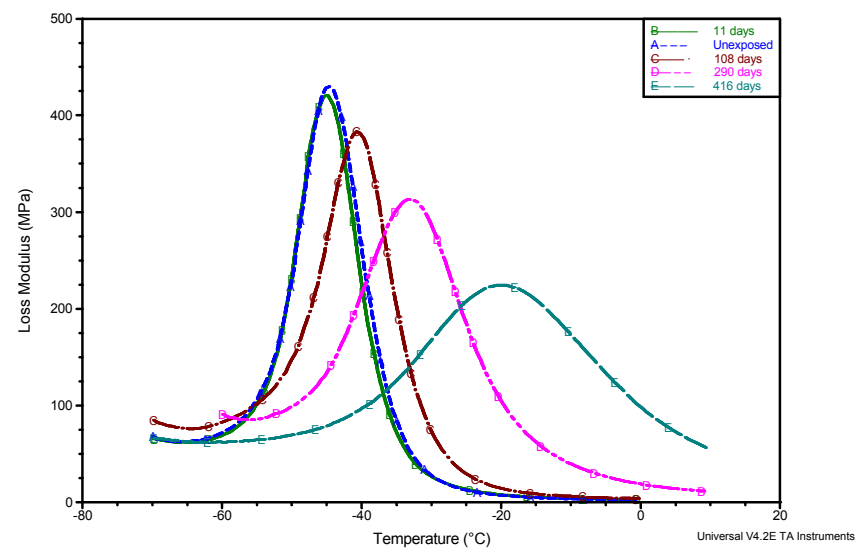

b.

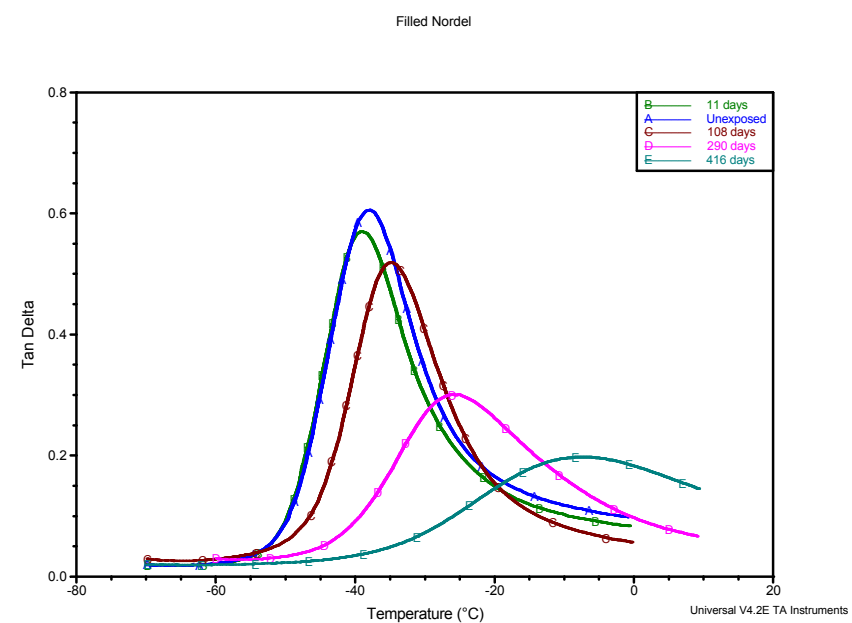

c.

Figure 6. Filled Nordel $^{\mathrm{TM}}$ : a. Storage Modulus, b. Loss Modulus, c. Tan Delta as a function of temperature and tritium exposure time. Color indicates time of tritium exposure as noted. All data $1 \mathrm{~Hz}$ and temperature increase at $1^{\circ} \mathrm{C} . /$ minute. 


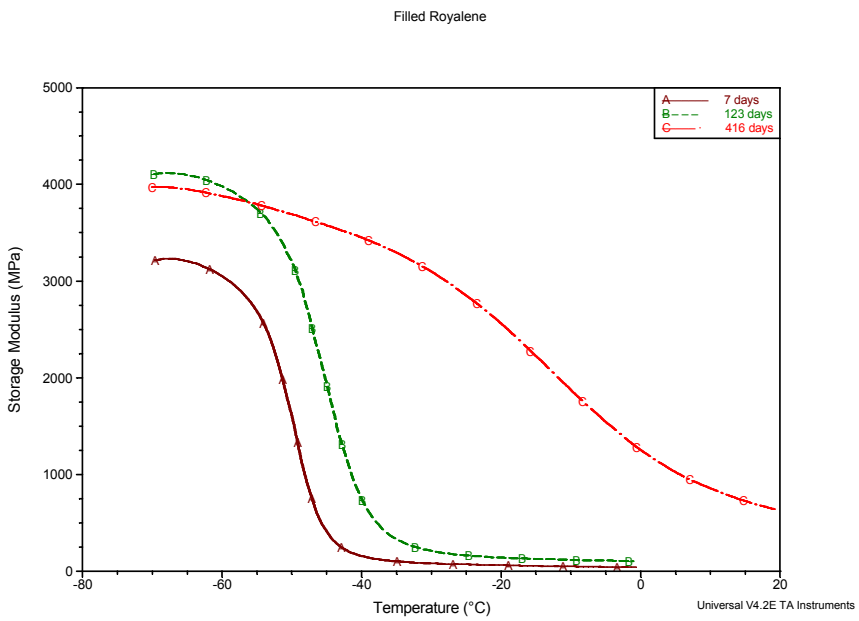

a.

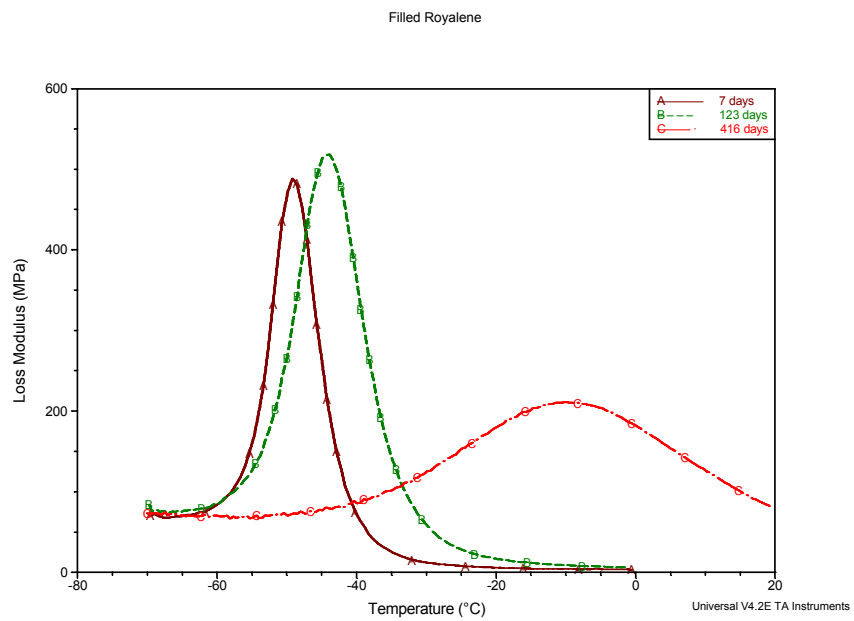

b.

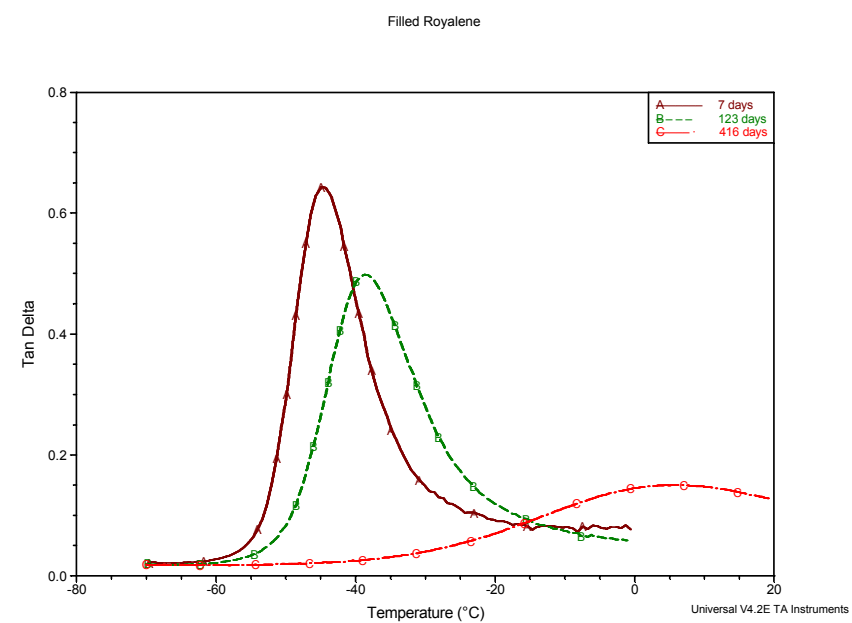

c.

Figure 7. Filled Royalene ${ }^{\circledR}$ : a. Storage Modulus, b. Loss Modulus, c. Tan Delta as a function of temperature and tritium exposure time. Color indicates time of tritium exposure as noted. All data $1 \mathrm{~Hz}$ and temperature increase at $1^{\circ} \mathrm{C}$./minute. 


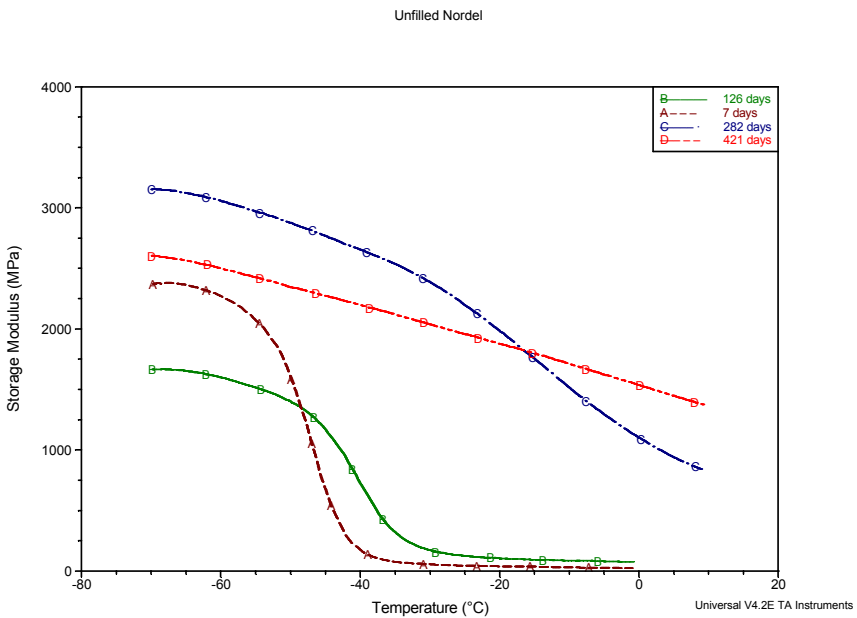

a.

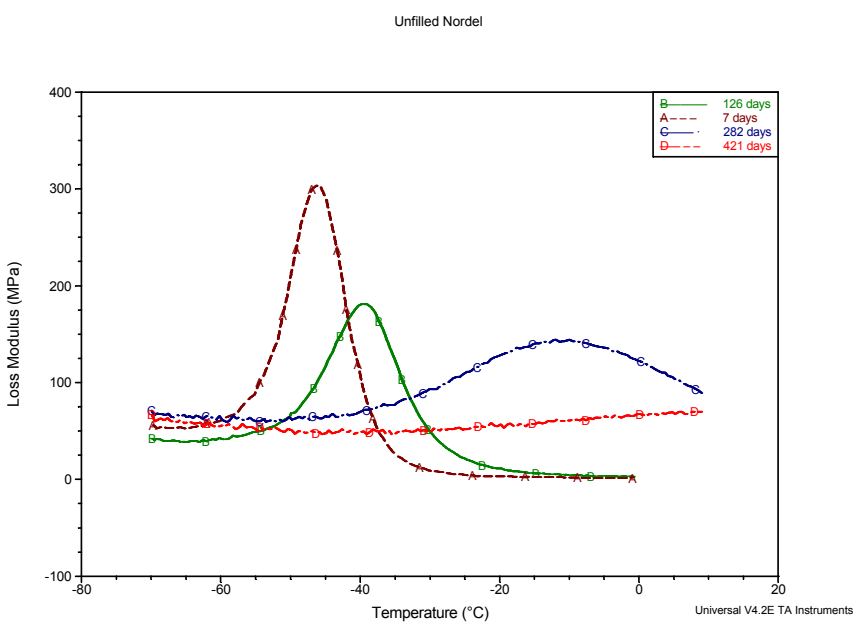

b.

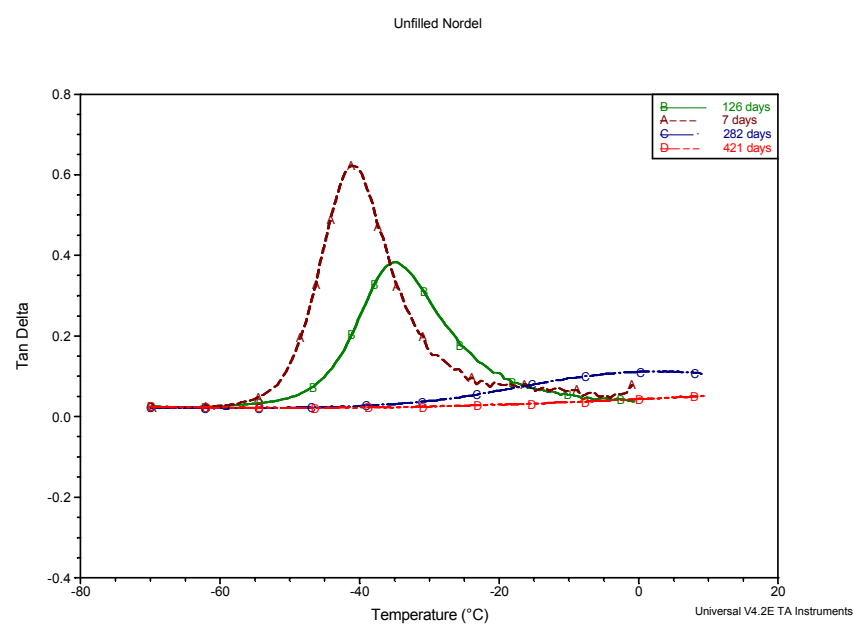

c.

Figure 8. Unfilled Nordel ${ }^{\mathrm{TM}}$ : a. Storage Modulus, b. Loss Modulus, c. Tan Delta as a function of temperature and tritium exposure time. Color indicates time of tritium exposure as noted. All data $1 \mathrm{~Hz}$ and temperature increase at $1^{\circ} \mathrm{C}$./minute. 


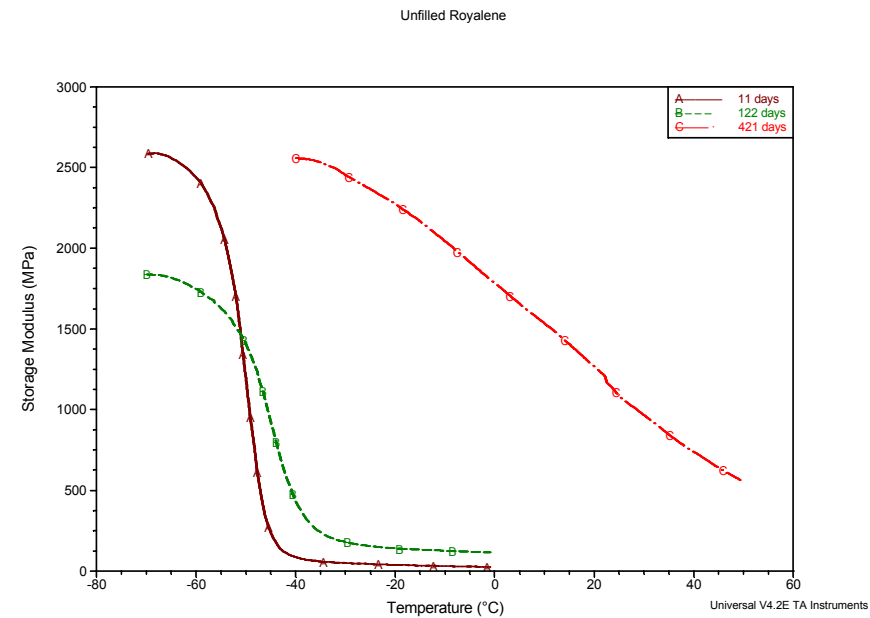

a.

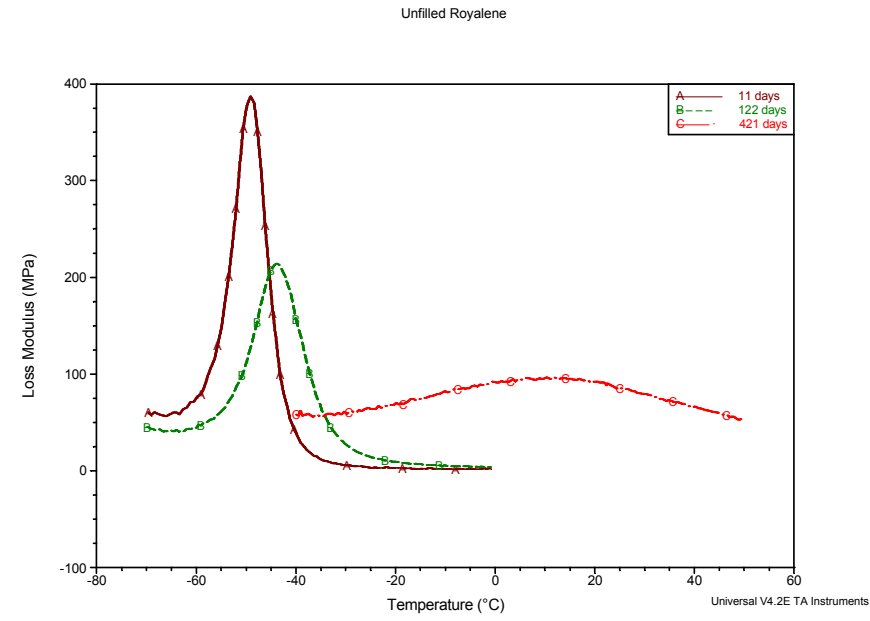

b.

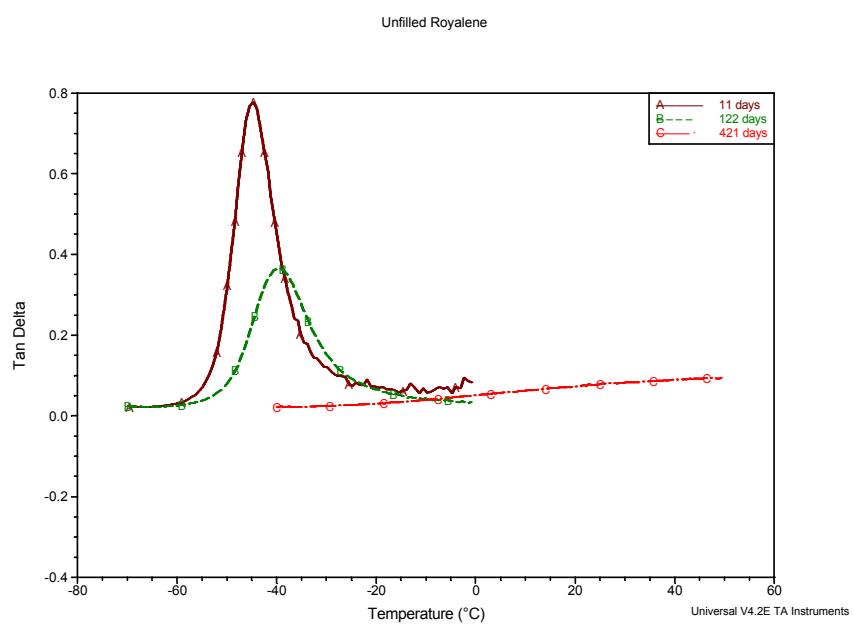

c.

Figure 9. Unfilled Royalene ${ }^{\circledR}$ : a. Storage Modulus, b. Loss Modulus, c. Tan Delta as a function of temperature and tritium exposure time. Color indicates time of tritium exposure as noted. All data $1 \mathrm{~Hz}$ and temperature increase at $1^{\circ} \mathrm{C}$./minute. 


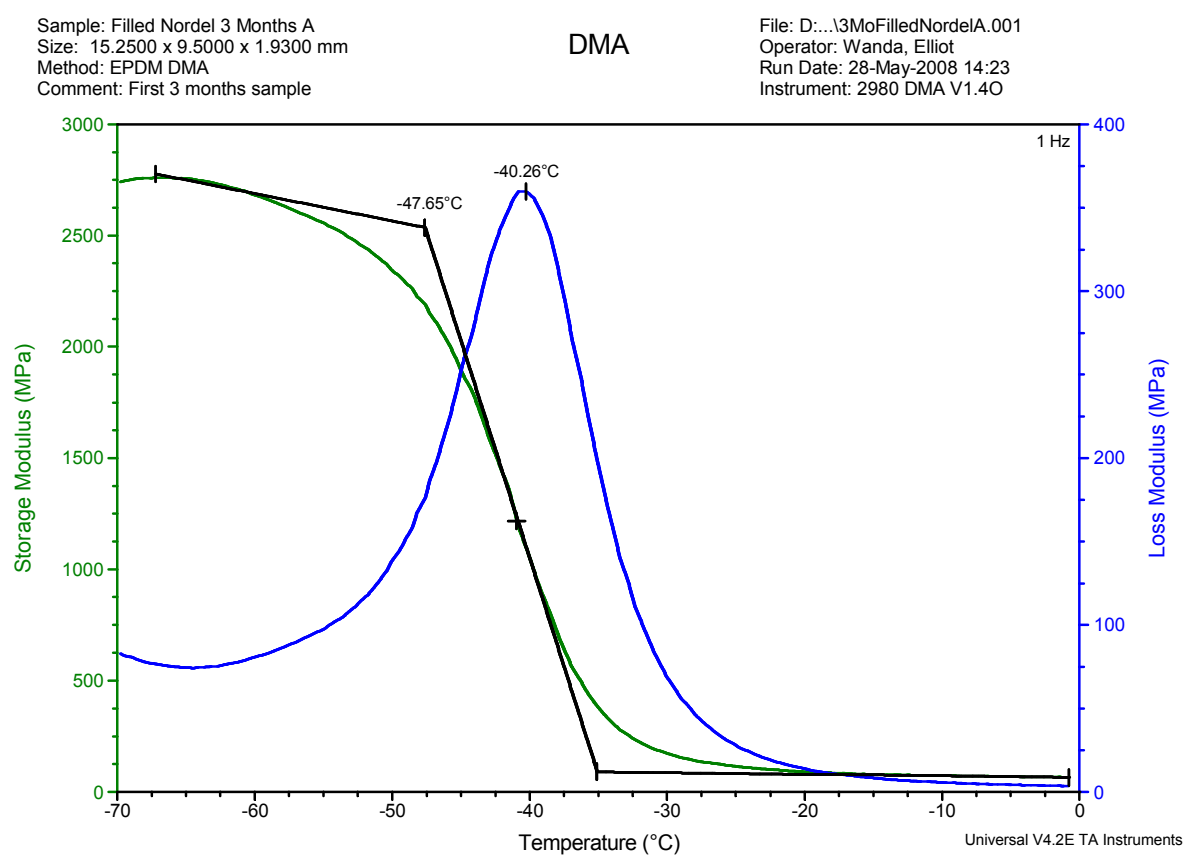

Figure 10. Storage modulus and loss modulus of filled Nordel ${ }^{\mathrm{TM}}$ with increasing temperature (data part of Figs. 6 a. and b.). ASTM E 1640 construction by DMA analysis software obtains $-47.7^{\circ} \mathrm{C}$. (tangent intersection), peak of loss modulus obtains $-40.3^{\circ} \mathrm{C} .1 \mathrm{~Hz}$ data, $1^{\circ} \mathrm{C} . /$ minute heating rate.

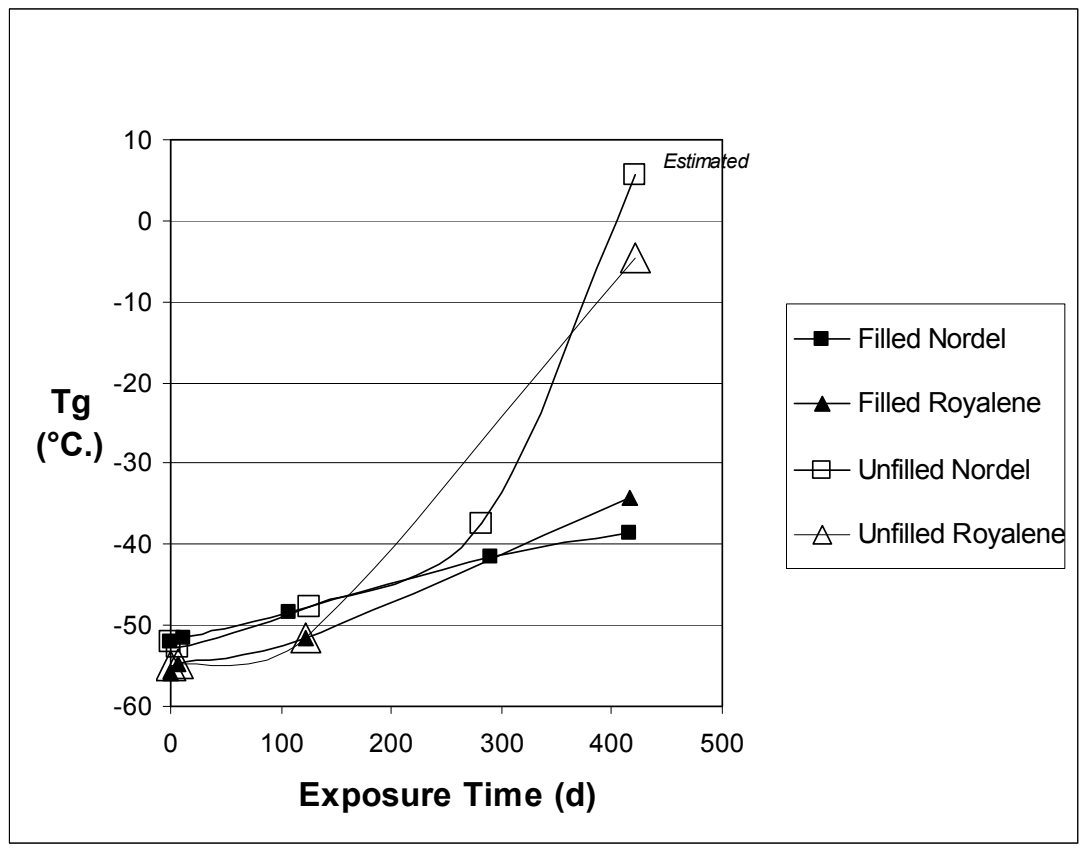

Figure 11. Glass Transition Temperature versus Tritium Exposure Time. Tg determined by ASTM E 1640 Tangent Intercept method. Longest exposure Tg for unfilled Nordel ${ }^{\mathrm{TM}}$ estimated from loss modulus. Most points average of two or three samples. 


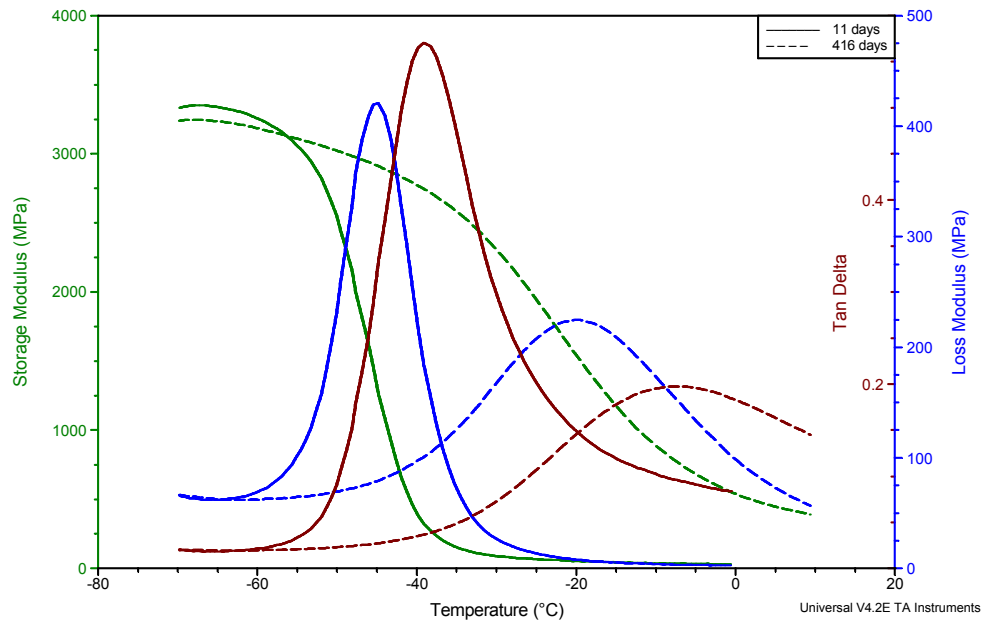

a.

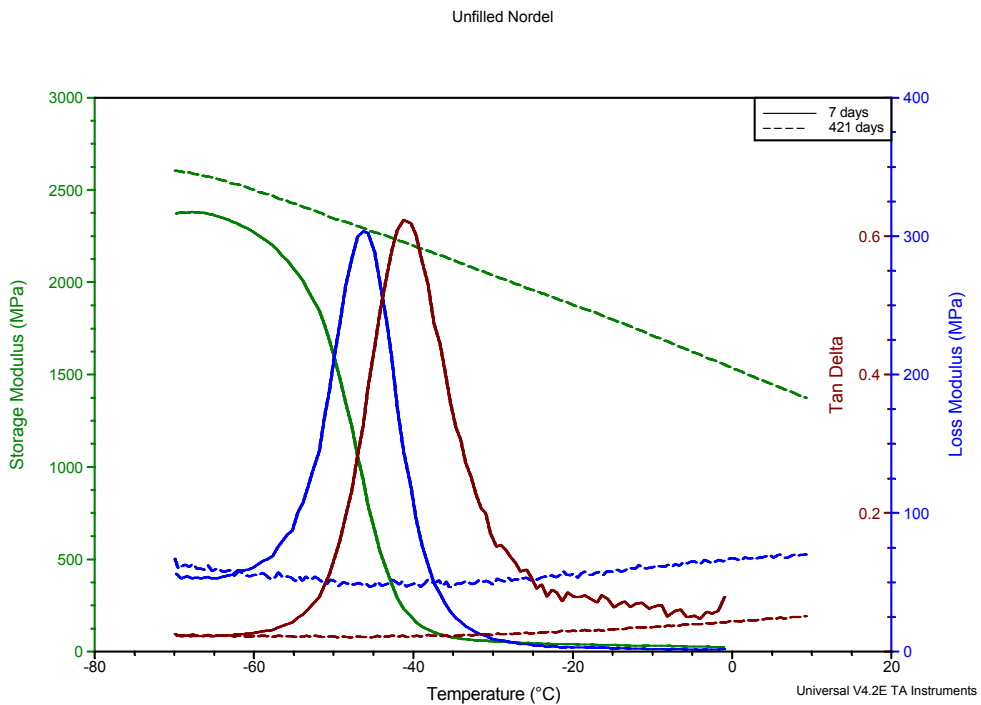

b.

Figure 12. Storage modulus (green), loss modulus (blue), and tan delta (red) versus temperature for (a.) filled Nordel ${ }^{\mathrm{TM}}$ and (b.) unfilled Nordel ${ }^{\mathrm{TM}}$, about about 1 week (solid lines) and about 420 days (dotted lines) tritium exposure. Note increased glass transition in storage modulus and increased loss modulus and tan delta peak temperatures for long tritium exposure filled $\operatorname{Nordel}^{\mathrm{TM}}$ (a.) and no transition or peak temperatures for unfilled Nordel ${ }^{\mathrm{TM}}$ after long tritium exposure (b.). All data $1 \mathrm{~Hz}$ and temperature increase at $1^{\circ} \mathrm{C} . /$ minute. 


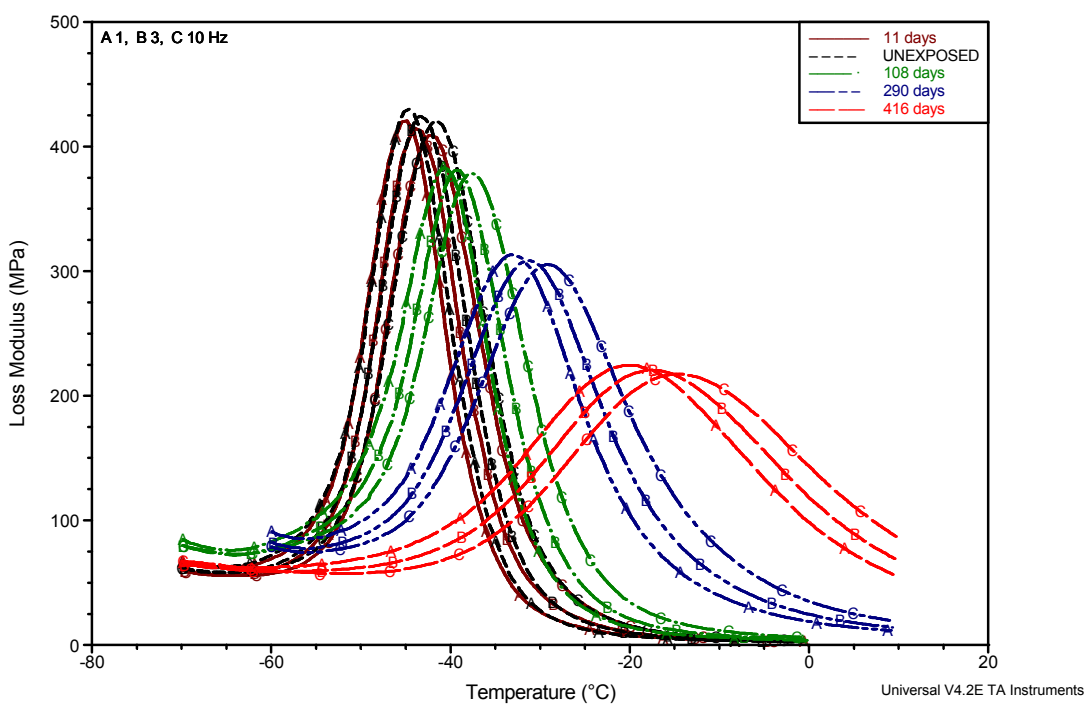

a.

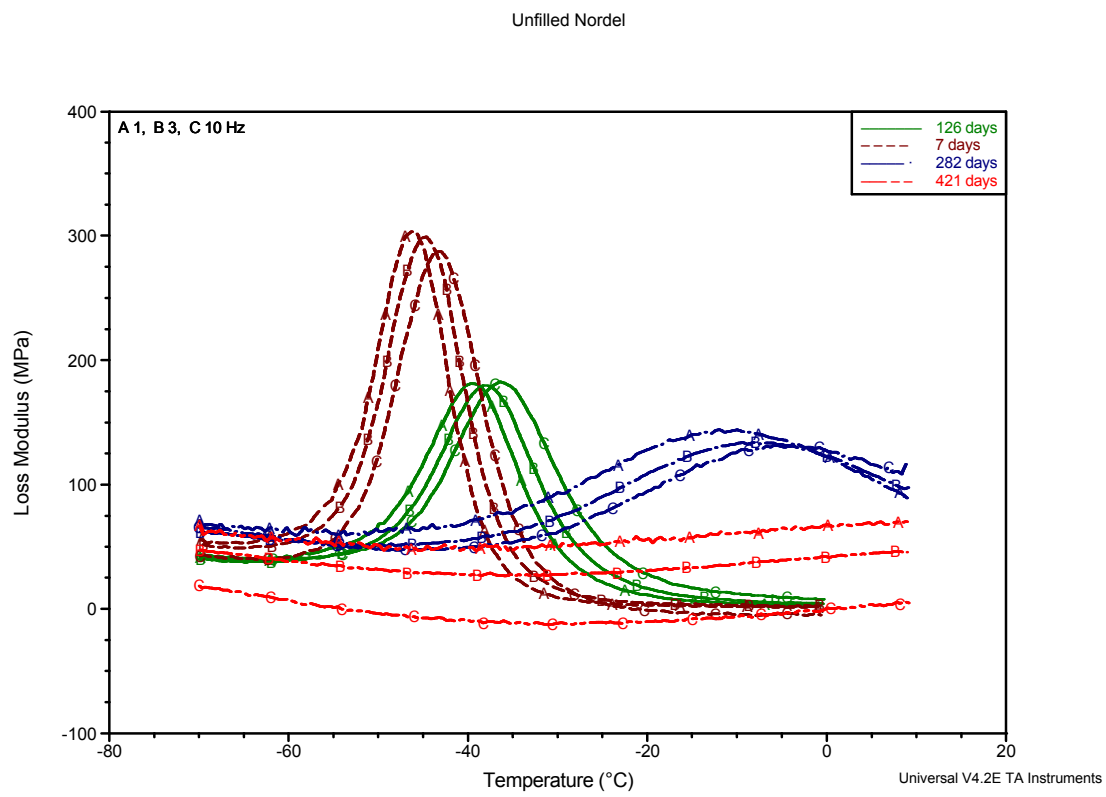

b.

Figure 13. Loss modulus of a. Filled Nordel ${ }^{\mathrm{TM}}$ and of $\mathrm{b}$. Unfilled Nordel ${ }^{\mathrm{TM}}$, after various days of tritium exposure (color) and at 1 (curve labled "A"), 3 (“B"), and 10 ("C") Hz applied load. Note peak temperatures increase with frequency at any given exposure time, and as the total exposure increases the viscous nature of the polymer disappears (the loss modulus peak value decreases). The 421 day exposure of unfilled Nordel ${ }^{\mathrm{TM}}$ has no loss peak at any of the frequencies tested. The decrease of the loss modulus peak value with increasing exposure time also reflects tritium effects. 


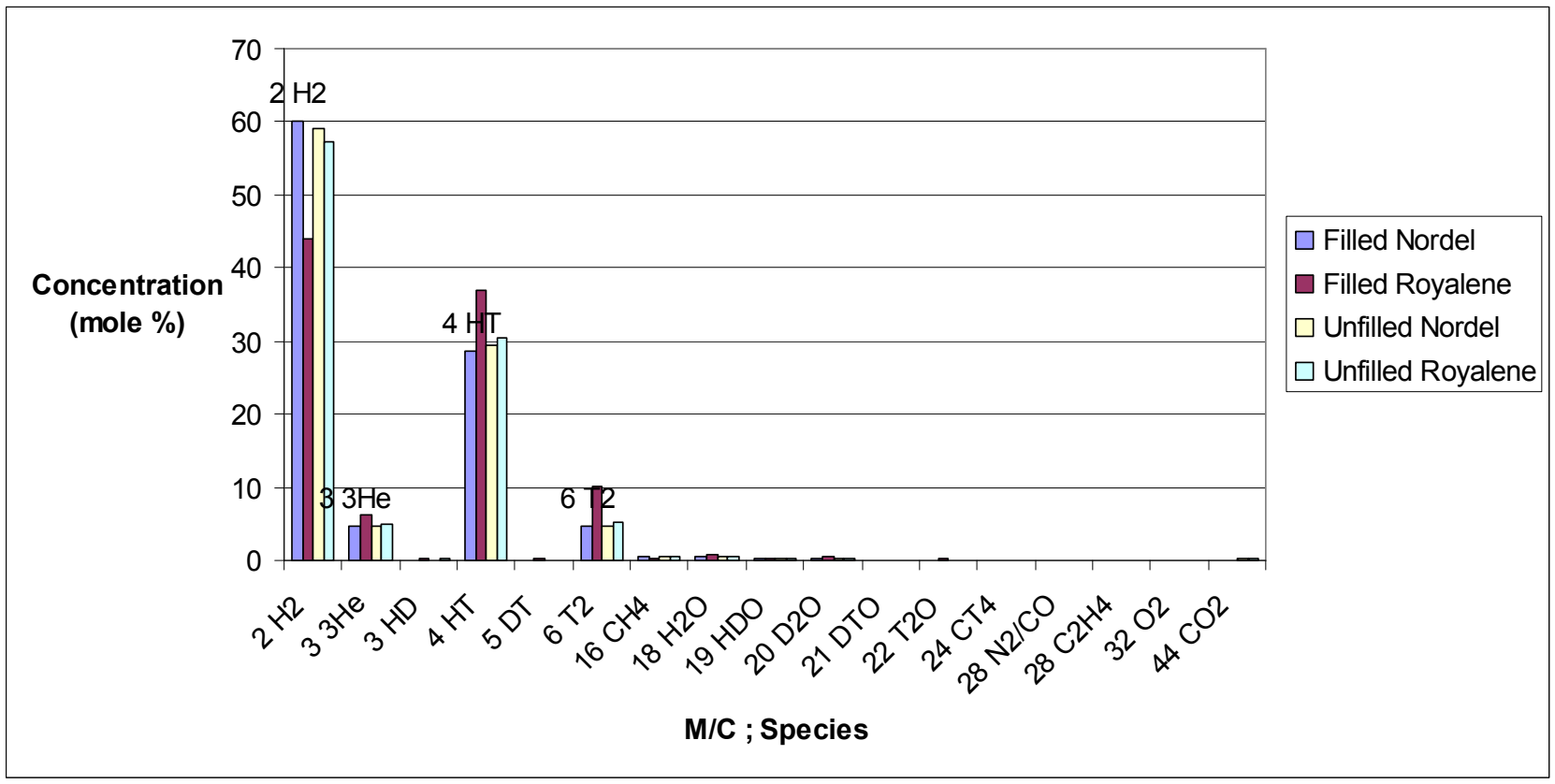

a.

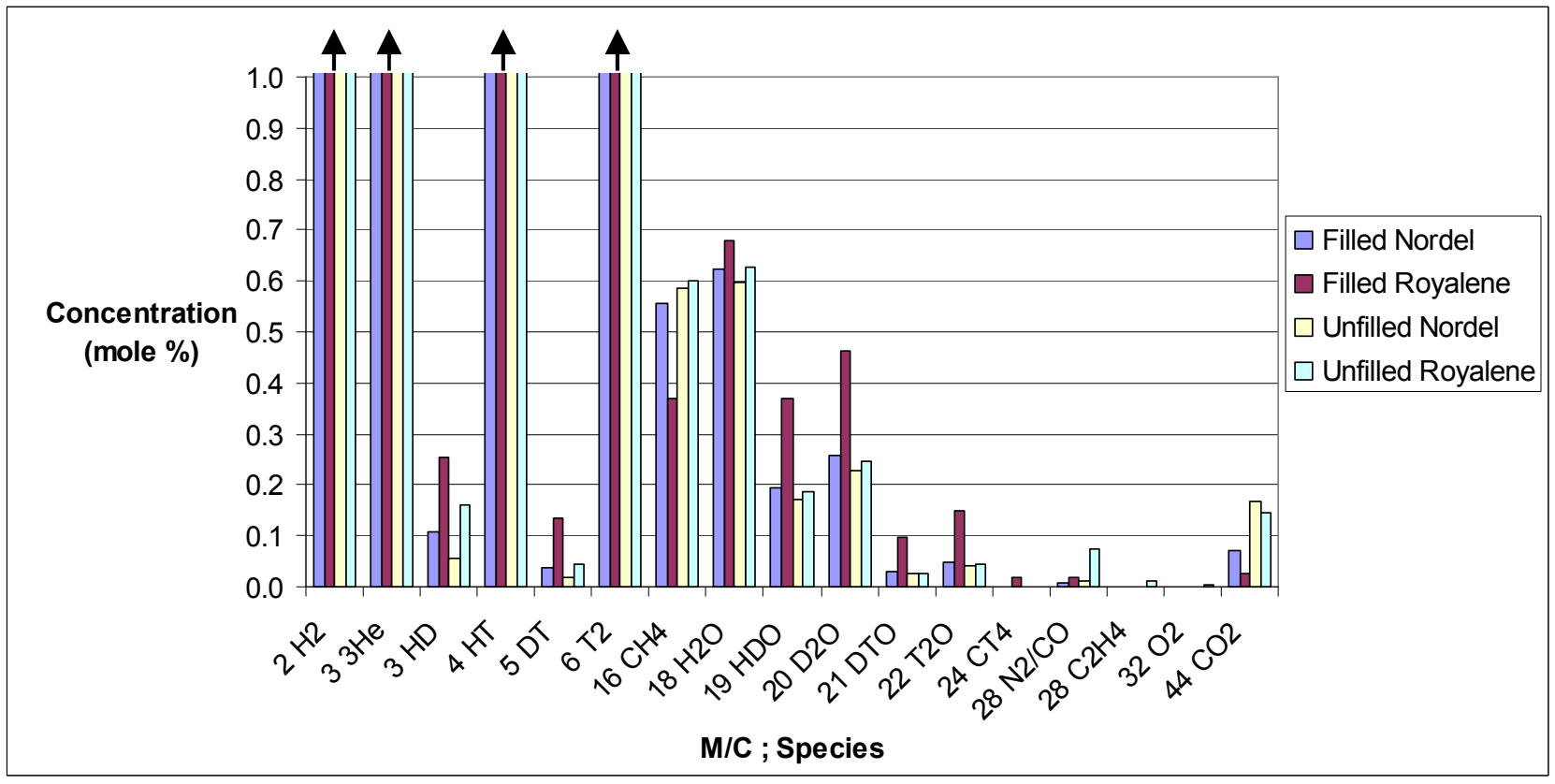

b.

Figure 14 Composition after 416 days exposure Filled Nordel ${ }^{\mathrm{TM}}$, Filled Royalene ${ }^{\circledR}$, and after 421 days exposure unfilled Nordel ${ }^{\mathrm{TM}}$, unfilled Royalene ${ }^{\circledR}$. a. Full scale, b. scaled to display low concentration species. 


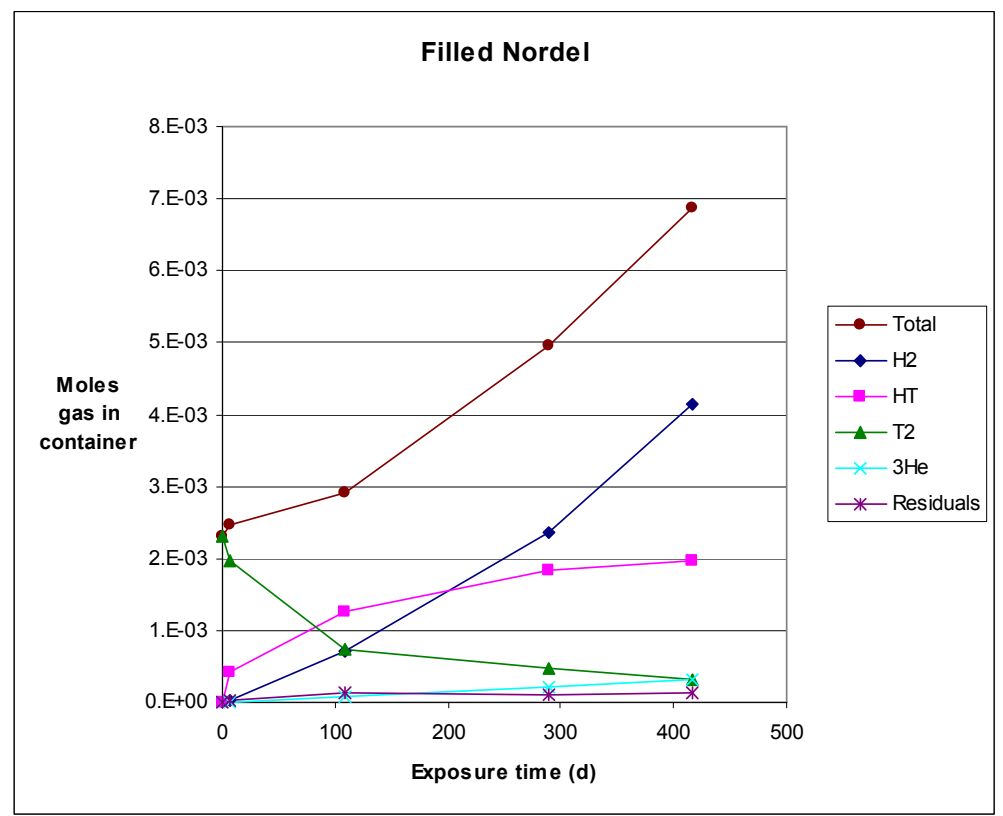

a.

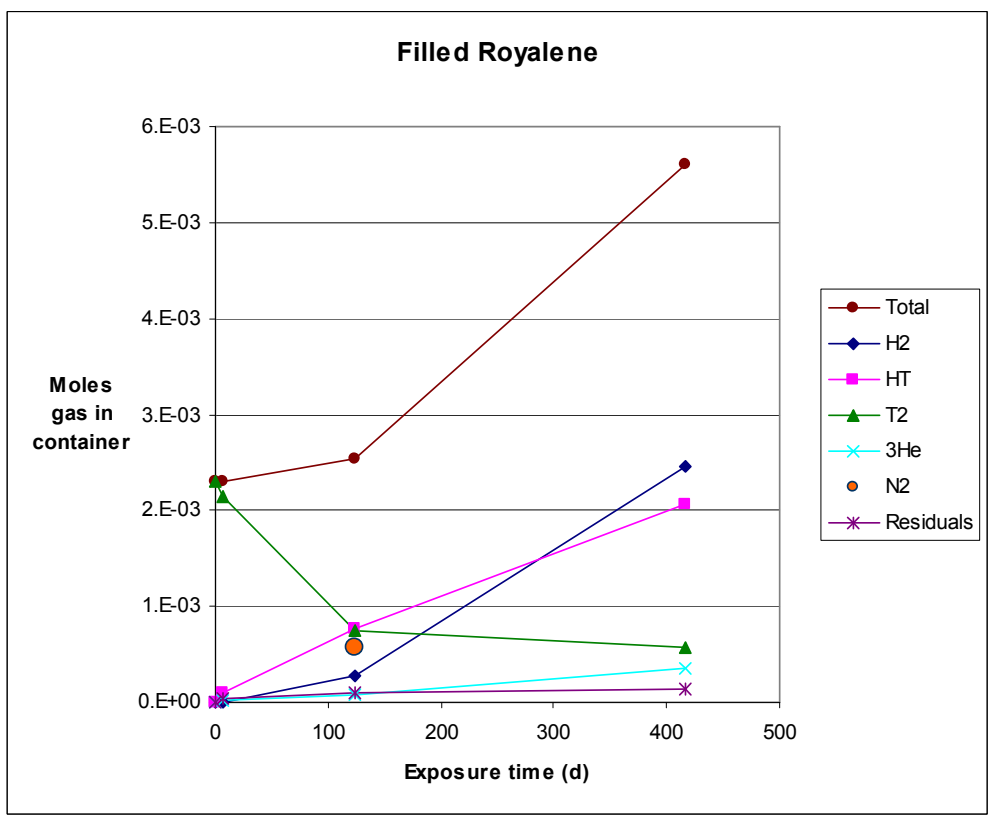

b.

Figure 15. Moles of gas of each species in container as a function of tritium exposure time, a. filled Nordel $^{\mathrm{TM}}$, b. filled Royalene ${ }^{\circledR}$. Note nitrogen observed in b. at 120 days, presumably a leak. 


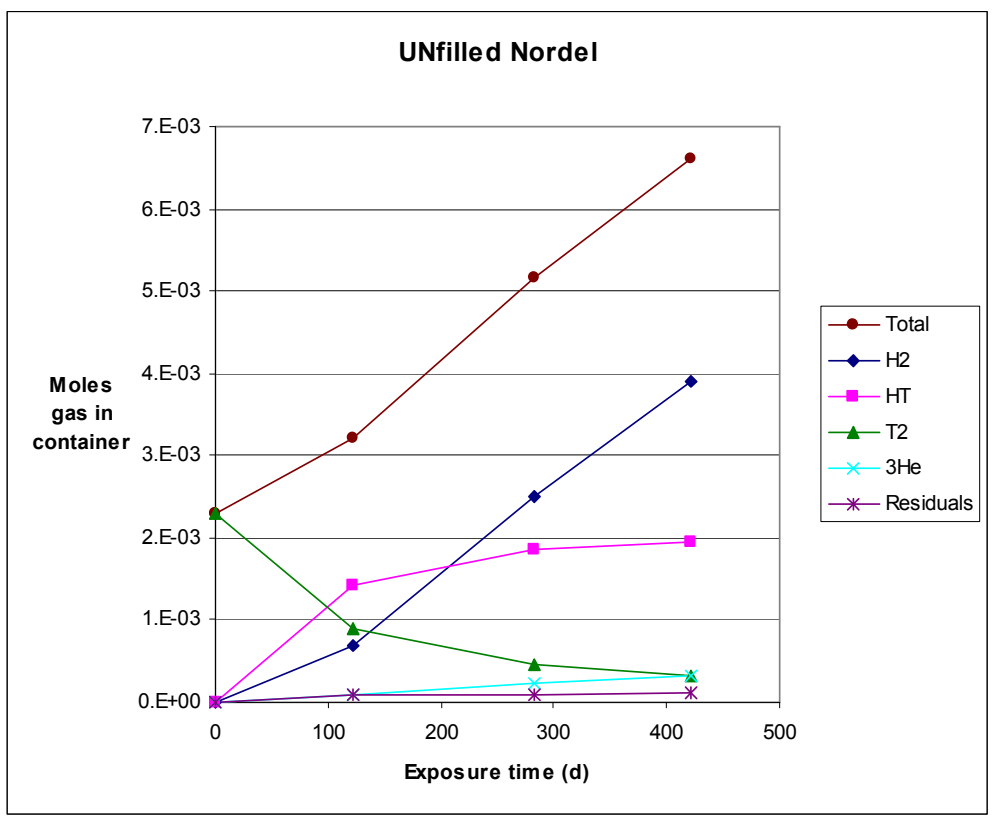

a. Unfilled Nordel ${ }^{\mathrm{TM}}$

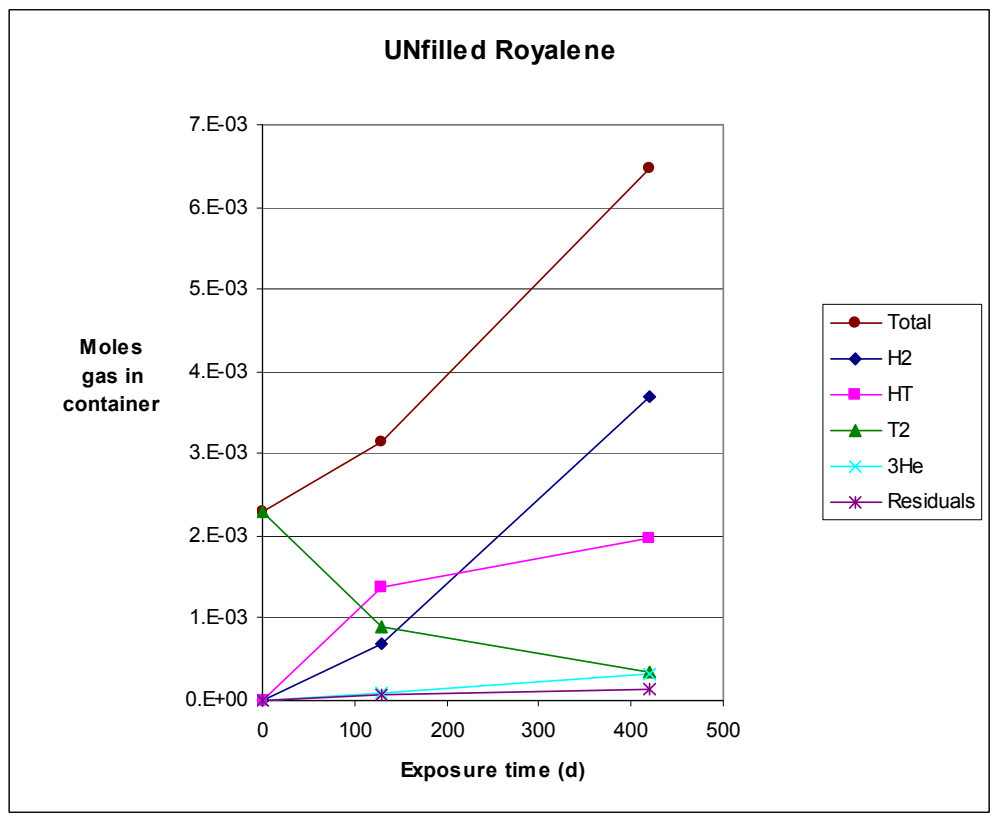

b. Unfilled Royalene ${ }^{\circledR}$

Figure 16. Moles of gas of each species in container as a function of tritium exposure time, a. unfilled Nordel $^{\mathrm{TM}}$, b. unfilled Royalene ${ }^{\circledR}$. 


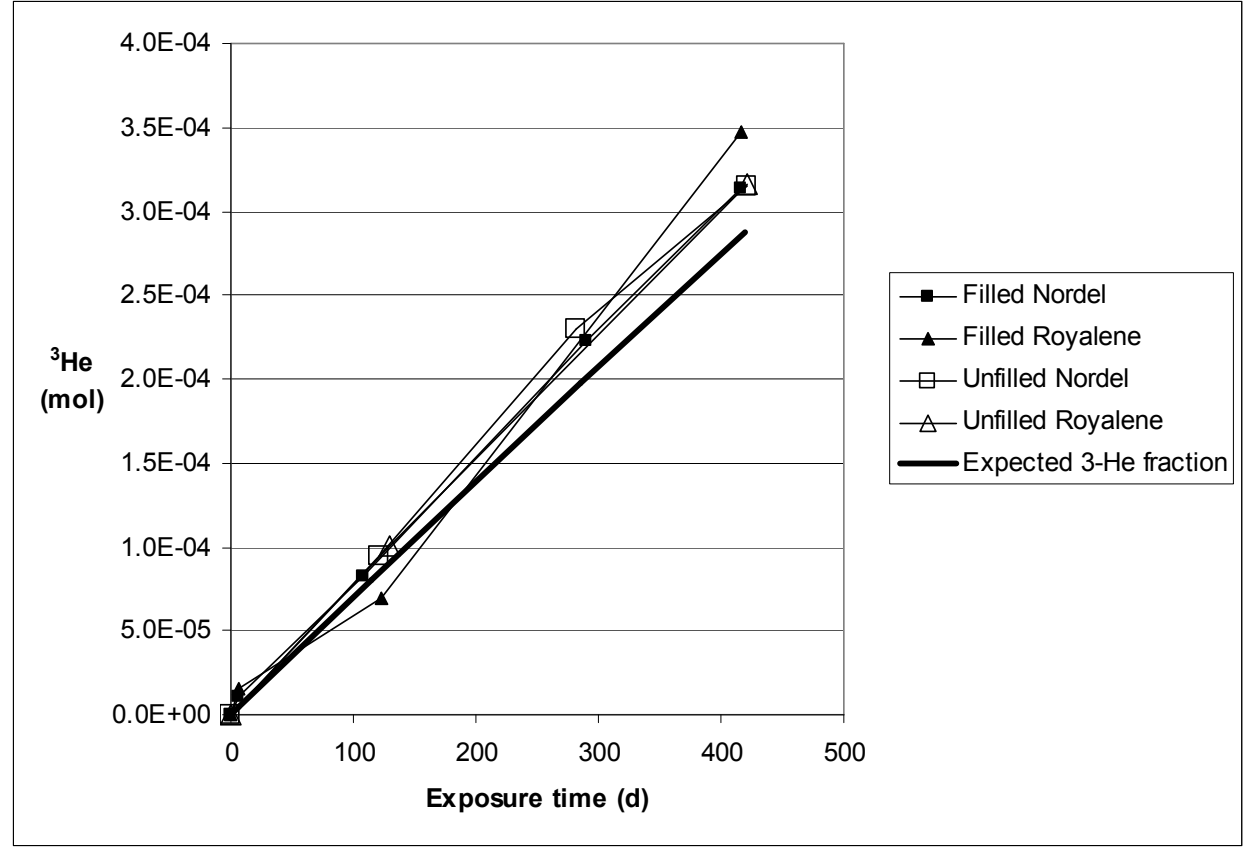

a.

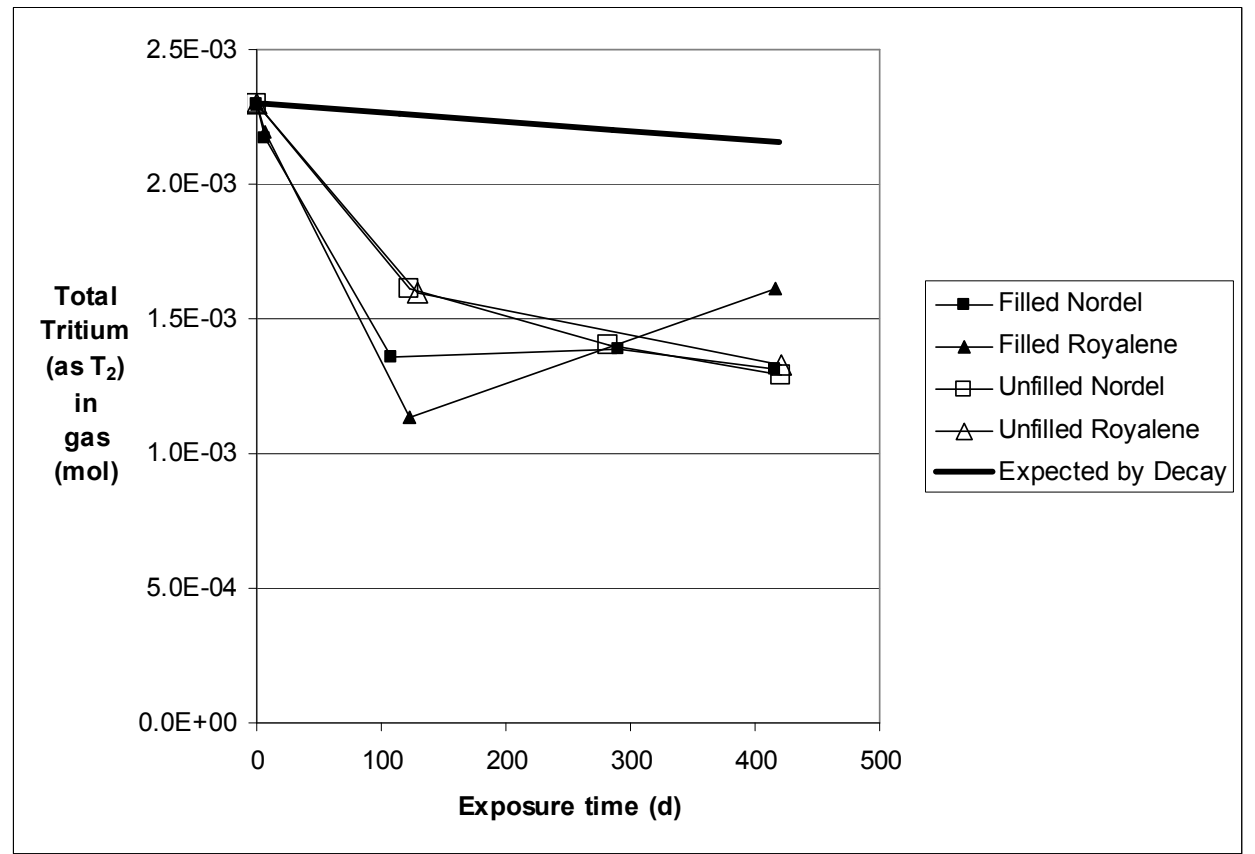

b.

Figure 17. Predicted and measured moles of a. 3-helium and b. tritium in containers at the end of exposures as a function of exposure time. Difference between expected and observed tritium in $b$. is presumably tritium incorporated in polymer. 
SRNL-STI-2009-00801 Rev. 0 